\title{
Normatywność antycypacji a normatywność predykcji. Dwa podejścia: fenomenologia i teoria przetwarzania predykcyjnego ${ }^{1}$
}

\author{
Michał Piekarski \\ Instytut Filozofii \\ Uniwersytet Kardynała Stefana Wyszyńskiego w Warszawie \\ m.piekarski@uksw.edu.pl
}

Przyjęto: 16 czerwca 2017; zaakceptowano: grudzień 2017

\begin{abstract}
Abstrakt
Celem niniejszego artykułu jest (1) przeanalizowanie normatywnego charakteru antycypacji, które są opisywane w fenomenologii; (2) wykazanie w ramach koncepcji przetwarzania predykcyjnego, że predykcje pełnią określone funkcje normatywne w procesach percepcyjnych; (3) uzasadnienie tezy, według której analizy mechanizmów normatywnych przeprowadzane przez badawczy przetwarzania predykcyjnego są bardziej efektywne i pozwalają na pełniejsze wyjaśnienie normatywności, niż ma to miejsce w fenomenologii. Chciałbym uzasadnić tezę, według której wyjaśnienia oferowane przez badania z zakresu przetwarzania predykcyjnego mają charakter normatywny. Są one takie, ponieważ normatywne są same mechanizmy predykcyjne.
\end{abstract}

Słowa kluczowe: percepcja; predykcja; antycypacja; normatywność; przetwarzanie predykcyjne; fenomenologia; wyjaśnienie

\footnotetext{
${ }^{1}$ Wstępna wersja tego tekstu została wygłoszona na Uniwersytecie Gdańskim 4 kwietnia 2017 roku na seminarium z cyklu „Perspektywy współczesnej fenomenologii”. Dziękuję uczestnikom tego spotkania za interesującą i pouczającą dyskusję, w tym szczególnie Witoldowi Płotce i Tomaszowi Kąkolowi. Pragnę również wyrazić podziękowanie dwóm anonimowym recenzentom, których uwagi w znacznym stopniu pozwoliły mi na ulepszenie i poprawienie pierwotnej wersji niniejszego artykułu.

Artykuł został sfinansowany ze środków Narodowego Centrum Nauki przyznanych na podstawie decyzji numer DEC-2017/01/X/HS1/00165.
} 


\section{Wprowadzenie}

W prezentowanym artykule przyjrzę się transcendentalnemu (fenomenologicznemu) oraz naturalistycznemu (opierającemu się na koncepcji przetwarzania predykcyjnego) podejściu do problemu normatywności. Zastanowię się, które ze stanowisk oferuje bogatsze i pełniejsze wyjaśnienie normatywnych własności mechanizmów antycypacyjnych obecnych w procesach percepcyjnych. Porównanie obu tych ujęć jest kluczowe dla wielu dyskusji prowadzonych w obrębie współczesnej filozofii. Jedną z nich jest dyskusja nad normatywnością, która ogniskuje się wokół sporu naturalizmu z antynaturalizmem. Niniejsze badania stanowią głos w tej debacie.

Późny Husserl uznawał percepcję za proces oparty (1) na doświadczeniu przedmiotów danych w jakiejś możliwej naoczności oraz (2) na antycypacjach potencjalnych działań cielesnych w świecie, które miały zostać następnie wypełnione przez odpowiednie działania (Madary, 2012). Konstrukcja ta ma doniosłe znaczenie dla możliwości rozwiązania wielu problemów filozoficznych dotyczących między innymi sporu o reprezentacje, problemu relacji zachodzących pomiędzy percepcją a działaniami, ale także kwestii natury normatywności i jej źródeł.

Badacze przetwarzania predykcyjnego twierdzą, że percepcja jest aktywnym i dynamicznym procesem realizowanym $\mathrm{w}$ środowisku, w którym odgórnie (top-down) budowany generatywny, wielopoziomowy model próbuje przewidzieć przepływ kolejnych ciągów oddolnie odbieranych (buttom-up) danych zmysłowych (Clark, 2013, s. 183). Podejście to opiera się na przekonaniu, że podstawowym zadaniem mózgu jest minimalizacja błędów predykcyjnych, które pojawiają się pomiędzy informacjami pochodzącymi ze świata a hipotezami tworzonymi na podstawie tych informacji i reprezentacjami, które konstytuują model świata posiadany przez dany organizm. Zadanie to jest podporządkowane celowi, jakim jest skuteczne działanie danego organizmu w środowisku (por. Clark, 2013, 2015, 2016; Friston, 2009, 2010; Hohwy, 2013)².

Niniejsze rozważania mają następującą strukturę. W §2 wprowadzę podstawowe pojęcia kluczowe dla zrozumienia prezentowanych tu badań. W §3-4 przeanalizuję fenomenologiczne pojęcie typiki doświadczenia i powiążę jego konstrukcję z antycypacjami odpowiednich własności przypisywanych przedmiotom danym w aktualnej naoczności na podstawie minionych doświadczeń. W §5 zajmę się tak zwanymi antycypacjami normalności, warunkującymi każde możliwe doświadczenie. W §6 zostanie wykazany normatywny charakter antycypacji jako (1) racji działania oraz jako (2) struktury konstytuującej

\footnotetext{
${ }^{2}$ Koncepcje oparte na idei przetwarzania predykcyjnego zyskują na znaczeniu we współczesnej kognitywistce, filozofii umysłu i filozofii nauki, co ściśle wiąże się z nadziejami wielu badaczy, że podejście to może doprowadzić do integracji prac nad tak zwanym poznaniem ucieleśnionym (koncepcje 4e - Embodied, Embedded, Extended, Enactive) (por. Allen, Friston, 2016; Clark, 2013; Gallagher, Allen, 2016).
} 
charakter aktualnie przeżywanych spostrzeżeń. Dalsze rozważania poświęcone będą (\$7) ogólnemu omówieniu teorii przetwarzania predykcyjnego oraz (§8) analizie tak zwanego wnioskowania aktywnego. §9 będzie dotyczyć normatywnego charakteru predykcji. W \$10 przeanalizuję zależności zachodzące pomiędzy badaniami z zakresu fenomenologii antycypacji a koncepcjami przetwarzania predykcyjnego w kontekście problemów normatywności percepcji i rozpoznawalności wzorców. W \$11 zaproponuję, aby rozważany przeze mnie spór pomiędzy transcendentalnym i naturalistycznym ujęciem normatywności sprowadzić do pytania o charakter wyjaśnienia tego, czym jest normatywność. Postawię tezę, według której analizy przeprowadzane w ramach koncepcji przetwarzania predykcyjnego mają większą wartość eksplanacyjną niż analizy fenomenologiczne. Wniosek ten może brzmieć arbitralnie zważywszy na to, że są to koncepcje, które znacznie więcej dzieli, niż łączy, niemniej ich porównanie jest o tyle zasadne, o ile pozwala mówić o dwóch różnych sposobach uzasadniania normatywności, to jest transcedentalnym i naturalistycznym (empirycznym). Z tego powodu twierdzę, że obie koncepcje w tym zakresie można ze sobą zestawiać. W Zakończeniu przedstawię ogólne wnioski.

\section{Pojęcie normatywności}

Rozpocznę od kilku uwag terminologicznych dotyczących znaczenia używanych w tym artykule pojęć. Kluczowym terminem dla prezentowanej analizy jest normatywność. W wąskim sensie przez normatywność można rozumieć wprost sformułowaną normę czy regułę działań, wywodzącą się z pewnej konwencji, zwyczaju czy uzusu społecznego. Przykładem tak rozumianej normatywności (choć bardziej zasadne jest mówienie tutaj o tworach normatywnych) jest prawo karne. W nim reguły są wyrażone explicite i wprost określają, które działania są z nimi zgodne, a które nie. To wąskie rozumienie normatywności leży poza problemami poruszanymi w tym artykule.

W szerokim sensie normatywność wiąże się z regułą bądź normą rozumianą jako pewien standard lub miara zgodności dla danego zachowania, działania czy na przykład sposobu mówienia. W tym znaczeniu normatywne są pewne niepisane reguły działań (przykładowo zasady savoir-vivre), wszelkie miary, pojęcia regulatywne czy idealizacyjne w nauce, wzorce (na przykład projektowania) itd. Takie rozumienie normatywności należy przeciwstawić ujęciom, które wiążą normatywność z powinnością i z tak zwanym błędem naturalistycznym. Problem uzasadnienia przejścia od tego, co jest do tego, że coś p o w in n o być, nie będzie poruszany przeze mnie w tym artykule. Proponowane tutaj ujęcie ściśle wiąże się z regularnym i względnie powtarzalnym 
charakterem pewnych zdarzeń w świecie ${ }^{3}$ i trzeba odróżnić je od podejścia, które wiąże się z tak zwaną normatywnością powinnościową. Należy zgodzić się z Humem, iż z faktu, że codziennie rano wstaje słońce, nie wynika, że słońce powinno wstać. Niemniej fakt, że słońce wstaje codziennie rano jest normatywny w tym sensie, że pozwala racjonalnym podmiotom planować swoje działania, przewidywać ich skutki itd. ${ }^{4}$. Można wyobrazić sobie kontrfaktyczny świat, w którym słońce wstaje raz na jakiś czas i niemożliwe jest przewidzieć, kiedy to nastąpi. W takim świecie fakt, jakim są wschody słońca, nie ma żadnej mocy normatywnej dla podmiotów działania żyjących $w$ nim. Nie pozwala on bowiem na planowanie, kontrolę czy przewidywanie czyichś działań lub zachowania.

Na potrzeby niniejszych analiz przyjmuję następujące rozumienie normatywności: normatywna jest taka własność, która jest konstytutywna (por. Bickhard, 2003, 2009; Friston, 2009) dla kontroli zachowania (działania) oraz struktury i treści wewnętrznego dla danego systemu poznawczego modelu świata. Jest to pewne uszczegółowienie szerokiego rozumienia normatywności. Tak rozumianą normatywność należy łączyć przede wszystkim z funkcjami bądź mechanizmami realizowanymi przez dany system podmiot czy organizm. Nazwę ją normatywnością pierwotną (NP).

Przykładowo: prowadzę auto. W moją stronę z wielką prędkością zbliża się samochód jadący pod prąd. Zakładam (przyjmuję hipotezę), że jeżeli sytuacja na drodze nie ulegnie żadnej zmianie, to istnieje duże prawdopodobieństwo, że jadący pod prąd pojazd wejdzie w kolizję z prowadzonym przeze mnie samochodem. Co robię? Mogę zjechać na pobocze, ale mogę również spróbować ominąć zbliżające się zagrożenie. Ostatecznie nie jest istotne, które działanie wybiorę. Istotne jest to, że przyjęte przeze mnie predykcje, minimalizujące potencjalne błędy predykcyjne, potraktuję jako zobowiązujące mnie do podjęcia j a ki e g oś działania. Predykcje „przedstawiają” zatem pewne spektrum możliwości do realizacji, w ramach którego można wybrać takie, a nie inne działanie $^{5}$. Według tezy NP predykcja jest normatywna w tym sensie, że zobowiązuje dany organizm czy system poznawczy do takiego, a nie innego działania. Ujęcie to zostanie doprecyzowane $\mathrm{w}$ trakcie prowadzonych tu analiz. NP w prezentowanych rozważaniach jest wiązana ze zdolnością do antycypacji (postulowaną

\footnotetext{
${ }^{3}$ Piszę „względnie” ponieważ powtarzalność nie jest tutaj warunkiem koniecznym tego, aby na przykład dane działanie miało charakter normatywny. Przykładowo: jednorazowy akt pomocy osobie poszkodowanej może stanowić wzór postępowania dla innych w takiej, a nie innej sytuacji. Zamiast mówić o względnej regularności, można również tutaj mówić o regularności potencjalnej.

${ }^{4}$ Przez racjonalny podmiot działania, w najbardziej ogólnym sensie, rozumiem taki podmiot, który kieruje się w swoich działaniach pewnymi racjami.

${ }^{5}$ Analizy wnioskowania aktywnego pozwalają uzasadnić takie rozumienie normatywności. Przedstawię je w dalszej części artykułu.
} 
przez fenomenologię) i tworzenia predykcji (opisywaną w ramach perspektywy przetwarzania predykcyjnego).

Oprócz normatywności pierwotnej będę jeszcze mówił normatywności weredycznej (NW), którą rozumiem następująco: dana hipoteza (predykcja) jest normatywna w tym sensie, że zostaje potraktowana jako obiektywnie ważna. Znaczy to, że jej przyjęcie zobowiązuje organizm do takiego zachowania, które wynika z przyjęcia prawdziwości danej hipotezy (por. Burge, 2000). Na przykład: gdybym nie uznał prawdziwości/fałszywości sądu „Będzie padać”, to sąd ten w żaden sposób nie mógłby stanowić przesłanki sylogizmu praktycznego. Uznanie prawdziwości/fałszywości danej predykcji pozwala utworzyć odpowiedni sąd, który następnie można zastosować w jakimś wnioskowaniu.

Jaka zatem zachodzi zależność pomiędzy NW i NP? Można zasadnie stwierdzić, że NP warunkuje możliwość NW6 . Ta ostatnia dotyczy wyboru odpowiednich działań, ta pierwsza zaś samej możliwości działania. Co to znaczy? Uznanie danego przewidywania za prawdziwe lub wysoce prawdopodobne, zobowiązuje podmiot do wyboru odpowiedniego działania. Niemniej owo „uznanie” jest możliwe tylko o tyle, o ile dana predykcja ma dla podmiotu charakter normatywny lub, mówiąc inaczej, zobowiązujący. Chcę przez to powiedzieć, że warunki prawdziwości pojawiają się wtedy, kiedy dana predykcja spełnia warunek normatywności. Ten ostatni należy rozumieć następująco: jeżeli posiadam odpowiednie przekonanie/predykcje, że $p$, to świat powinien być $p$ (por. Crowell, 2013, s. 128-135; Rowlands, 2012). To oznacza, że istnieje różnica pomiędzy tym, co powoduje moje przekonanie, że $p$, a tym, co powinno powodować to przekonanie ${ }^{7}$. Dopiero po uznaniu, że moje przekonanie/predykcja spełnia ten warunek, mogę zacząć mówić o jego prawdziwości. Prezentowane tutaj

\footnotetext{
${ }^{6}$ Teza ta w pewnym stopniu wiąże się z przyjęciem przesłanki, według której każdy akt percepcji jest skierowany na działanie. Przesłanka ta, którą w niniejszym tekście przyjmuję, zakłada pewne rozwiązania dotyczące natury i wyjaśniania percepcji, które są zgodne z interdyscyplinarnym podejściem do rozumienia procesów percepcyjnych jako u cieleśni onych i os a d z o n y h (por. Robbins, Aydede, 2008, s. 3-10).

${ }^{7}$ Rowlands powiada: „Nie wszystko bowiem co faktycznie tworzy moje przekonanie, że stoi przede mną koń, powinno je tworzyć: osioł stojący przede mną, który rzeczywiście kauzalnie tworzy moje przekonanie [dot. konia - przyp. tłum.], nie powinien go tworzyć. Tworzy on moje przekonanie, ale nie powinien. I dlatego moje przekonanie jest fałszywe. Tym samym więc przekonania mogą błędnie reprezentować - mogą być fałszywe - tylko dlatego, że przekonania przedstawiają normatywne założenia o świecie” (Rowlands, 2012, s. 351).

${ }^{8}$ Dobrze to przekonanie wyraża Crowell: „The meaning of my act makes a kind of claim on the world, set sit up as a norm under something like a description, such that my perception is veridical if the world includes a candel [Crowell's example - przyp. M.P.] just as I take it my perception [...]. To perceive something as a blue candle is to hold not only that the world contains this candle just as I take it in my perception, but also just as it would show itself if I moved around to view it from another angle. The normative in perception supports a peculiar sort of counterfactual, one that is both more familiar and also more obscure than the sort sustained by what is logically entailed by the judgment «This is a candle»" (Crowell, 2013, s. 129).
} 
ujęcie normatywności odbiega od potocznego rozumienia tego terminu w kategoriach obowiązku czy powinności moralnej bądź ontologicznej ${ }^{9}$.

Po wstępnych uwagach przechodzę do analizy pojęcia antycypacji obecnego w fenomenologii Husserla.

\section{Typika i antycypacja}

Pojęcie typiki Husserl wprowadził chcąc wyjaśnić sposób wyprowadzania z doświadczenia pojęć. Kierował się przekonaniem, że poznanie danej sfery przedmiotowej nigdy nie jest w sposób ścisły nieokreślone czy oparte na zupełnej nieznajomości. Skoro wszelkie przeżycia intencjonalne, co wiadomo z analiz fenomenologii czasu, mają swój tak zwany horyzont doświadczeniowy ${ }^{10}$, to można przyjąć, że wszelkie możliwe doświadczenie opiera się na „pewnej wiedzy i współwiedzy o danej rzeczy” (Husserl, 2013, s. 41). Doświadcza się tego, co nieznane, w odniesieniu do tego, co już poznane. Pierwotną formą takiej wiedzy nie jest nieznajomość, ale właśnie znajomość. To, co nieznane, zostaje ujęte $\mathrm{w}$ kontekście tego, co już poznane. Pojedynczy przedmiot jest spostrzegany w polu innych przedmiotów, które stanowią przedmioty jakiegoś „możliwego doświadczenia"”. Problem z opisywaniem za pomocą pojęć doświadczenia wiąże się z niejasnym sposobem, w jaki ogólne ze swej istoty pojęcia empiryczne mogą odnosić się do przedmiotów, które są jednostkowe i konkretne. Pojawia się pytanie: jak możliwe jest podpadanie indywidualnych przedmiotów pod wiele różnych ogólnych pojęć? Z fenomenologicznego punktu widzenia nie jest to problem z zakresu semantyki lub filozofii języka, ale zagadnienie dotyczące sposobu konstytuowania się relacji poznawczych ${ }^{11}$.

Husserl rozważa następujący przykład: widząc jamnika, ujmuje się go pojęciowo jako pewnego przedstawiciela gatunku „pies”. Analogicznie postępuje się w sytuacji, w której spostrzega się wyżła, dobermana czy ratlerka. Bez trudu

\footnotetext{
${ }^{9}$ Więcej na temat pojęcia normatywności i jego możliwych rozumień piszę w innej publikacji (Piekarski, 2018a).

${ }^{10}$ Husserl w Wykładach z fenomenologii wewnętrznej świadomości czasu (1989) powiada, że skierowanie ku przyszłości odbywa się na dwa sposoby: (1) przy pomocy protencji, która ujmuje naoczność daną w oczekiwaniu oraz (2) przez horyzont tego, co oczekiwane. Ów horyzont jest z jednej strony konstytuowany przez retencję, z drugiej zaś wydaje się współkonstytuowany przez intencjonalną protencję. Ta ostatnia jednak jest podporządkowana prymarnej funkcji pełnionej przez retencję. (Bielawska (2013) podkreśla, że dokonywanie przez Husserla analizy protencji są dużo uboższe niż przeprowadzane przez niego analizy retencji).

${ }^{11} \mathrm{~W}$ tym kontekście pojawia się również pytanie o pojęciowy charakter doświadczenia, mianowicie: czy treści dane w percepcji mają jakiś składnik pojęciowy. Percepcja w takim ujęciu to pewien rodzaj myślenia ukierunkowany na pojęciowe treści obecne w materiale zmysłowym (McDowell, 1994). Tak rozumianemu konceptualizmowi przeciwstawia się non-konceptualizm (por. Gunther, 2003). Należy jednak pamiętać, że oba te podejścia mają swoje silniejsze i słabsze wersje, które wiążą się nie tylko z kwestią (nie)pojęciowej natury treści, ale także (nie)pojęciowej natury stanów psychicznych. Problem ten jest szeroko komentowany również na gruncie fenomenologii (por. Crovell, 2013; Hopp, 2010; Mazijk, 2017). Na gruncie polskim kwestię tę omawia Piotr Kozak (2015).
} 
można pomyśleć sytuację, w której widzimy psa nieznanej nam rasy lub zwierzę, które określilibyśmy jako „psopodobne” czy „psowate”. Wydaje się, że istnieje pewną skłonność, która umożliwia podporządkowanie takiego, a nie innego przedmiotu pod typ „pies”. W doświadczeniu potocznym, które można przeciwstawić naukowemu, rozpoznanie psa jako przedstawiciela pewnego typu raczej nie jest ufundowane na określonej wiedzy biologicznej i taksonomicznej o psach. Wydaje się, że owa możliwość opiera się ujęciu pewnych podobieństw albo analogii, które warunkują postawienie sądu „To jest pies”. Tego rodzaju ujęcie nie ma charakteru statycznego przypisania pewnej własności ze zbioru własności przynależnych kategorii [PIES], lecz ma charakter antycypacji. Co to znaczy? Husserl powiada: „Widząc psa, antycypujemy od razu jego dalsze własności, jego typowy sposób jedzenia, zabawy, biegania, skakania itd. Nie widzimy teraz jego uzębienia, ale choć nigdy jeszcze nie spotkaliśmy tego psa, wiemy z góry, jak ono będzie wyglądać, określone nie indywidualnie, lecz właśnie typowo, albowiem już od dawna i często doświadczaliśmy, że u «takich» zwierząt, "psów», występuje «uzębienie» i tak a tak typowo wygląda”(Husserl, 2013, s. 314). Uogólniając można powiedzieć, że to, czego doświadcza się w odniesieniu do jednego przedmiotu, ulega antycypacyjnemu przeniesieniu na każdy inny przedmiot jakiegoś możliwego doświadczenia, który jest obdarzony pewnymi typowymi cechami im wspólnymi. Zdaniem fenomenologa każda rzecz posiada określoną formę typowości, która opiera się na jej indywidualnych wyróżnikach (Husserl, 2013, s. 312). Pojawia się jednak pewna wątpliwość. Na czym polega szczególna rola antycypacji? Dlaczego Husserl podkreślał anty-cypacyjny charakter owego przypisania własności?

\section{Czym jest typ?}

Husserl wprowadził pojęcie typu w fenomenologii genetycznej na oznaczenie szczególnego rodzaju przedpredykatywnej wiedzy, która umożliwia procesy percepcyjne. Przykładowo: kiedy spostrzegam kawałek szarlotki, to oczekuję takiego, a nie innego smaku, aromatu itd. Zdaniem Husserla owo oczekiwanie nie jest wiedzą w sensie ścisłym, ale raczej szczególnego rodzaju z n a j o m o ścią, którą podmiot posiada zanim będzie w stanie ująć dany przedmiot w pełni zmysłowy sposób. Przedpredykatywna wiedza nie odnosi się jednak do tej indywidualnej szarlotki, ale raczej do przedmiotu „tego rodzaju” (Lohmar, 2014, s. 49). Taka „wiedza” powstaje na podstawie wcześniejszego doświadczenia przedmiotów należących do takiego, a nie innego rodzaju. Z tego powodu trzeba odróżnić typy odnoszące się do pojedynczych przedmiotów, od typów, 
które oznaczają grupy przedmiotów (Lohmar, 2013, s. 147-167) ${ }^{12}$. Typy są konstytutywne dla percepcji w takim sensie, w jakim, zdaniem Husserla, pojęciowa wiedza predykatywna ufundowana jest na przedrefleskyjnej i przedpojęciowej wiedzy przedpredykatywnej. Lohmar powiada, że po pierwsze typy kierują percepcją rozumianą tutaj jako aktywność konieczna do utworzenia reprezentacji przedmiotu, po drugie zaś p o m a g a ją w interpretacji treści spostrzeganych przedmiotów (Lohmar, 2014, s. 53-54, 56).

Można teraz stwierdzić, że „proces” typizacji polega na antycypacyjnym przenoszeniu pewnej informacji z jednego przedmiotu, danego w jakimś przeszłym doświadczeniu, na inny, ujawniający się $\mathrm{w}$ doświadczeniu obecnym ${ }^{13}$. Z tego właśnie powodu niektórzy wiążą fenomen typu z fenomenem oczekiwania (Ferencz-Flatz, 2014, s. 66). Owo oczekiwanie nie odnosi się jednak do przyszłości, tak jak to miało miejsce w Wykładach z fenomenologii wewnętrznej świadomości czasu, ale właśnie do teraźniejszego doświadczenia, które konstytuuje się na podstawie doświadczenia minionego (Husserl, 1989, s. 66). Przedmiot, który zostaje ujęty jako podpadający pod dany typ jest jednostkowy. Antycypacja, która ma umożliwiać owo ujęcie ma charakter ogólny. Przyjrzę się temu nieco bliżej. Należy rozważyć trzy możliwości rozumienia typów:

(1) Typ jako kategoria,

Bycie typem (na przykład psa) charakteryzuje się jako bycie podmiotem, któremu przypisuje się skończony zbiór własności takich jak przykładowo \{uzębienie; machanie ogonem; szczekanie; istota zmysłowa\}. Jego poznawczym odpowiednikiem będzie pewna reprezentacja pojęciowa. Wydaje się, że taki uporządkowany zbiór ułatwia rozpoznanie czegoś jako przedstawiciela psowatych. Ale czy jest tak na pewno? Można sobie wyobrazić jakieś stworzenie, które nie będzie posiadało wszystkich tych własności, ale będzie psem. Można powyższy zbiór rozszerzyć o kolejne własności, nie wydaje się jednak, aby przesądziło to sprawę. Czy są to własności konieczne dla bycia psem, czy tylko wystarczające? Przecież niemy czy pozbawiony ogona pies dalej będzie ujmowany jako pies. Charakterystyka typów oparta na istnieniu pewnej treści wspólnej dla różnych przedmiotów nie jest satysfakcjonująca ${ }^{14}$.

\footnotetext{
${ }^{12}$ Można je dzielić od najbardziej ogólnych w stylu „przedmiot” albo „żywa istota” przez takie jak na przykład „pies”, „rybopodobny” aż po szczegółowe w rodzaju ,jamnik”, „trzyletnie dziecko” itd.

${ }^{13}$ Alfred Schütz (1962) zwrócił uwagę na istnienie ścisłego związku, jaki zachodzi pomiędzy typizacją a antycypacją. Każdy przedmiot możliwego doświadczenia jest wstępnie dany i doświadczany w odniesieniu do pewnego horyzontu (wewnętrznego i zewnętrznego). Z tego powodu określił on doświadczenie jako antycypację horyzontalną. Znaczy to, że konkretny przedmiot jest nie tylko doświadczany jako taki, a nie inny, ale jest również ujmowany jako przedstawiciel takiego, a nie innego typu (jako człowiek, zwierzę lub roślina itd.).

${ }^{14}$ Charakterystyka ta wiąże się ściśle z klasyczną teorią pojęć, według której o przynależności przedmiotu do zakresu danej kategorii lub pojęcia decyduje posiadanie pewnych stałych i istotnych
} 
(2) Typ jako prototyp.

Typ jest prototypem, jeżeli (a) stanowi pewną wewnętrzną własność rzeczy, charakterystyczną dla wielu różnych indywiduów (Youguo i in.,. 2008) lub (b) jest najlepszym reprezentantem czy centralnym elementem danej kategorii (Rosch, 1978; Kleiber, 2003). Przyporządkowanie danego przedmiotu do określonego typu jest możliwe poprzez odniesienie informacji na temat tego przedmiotu pochodzącej od zmysłów do takiego prototypu, którego ujęcie wiąże się z posiadaniem wiedzy na temat danej klasy czy grupy przedmiotów.

(3) Typ jako zbiór własności opartych na asymetrycznym podobieństwie ${ }^{15}$.

Byciem typem można również wiązać z czymś, co Alfred Schütz nazwał asymetrycznym podobieństwem (Schütz, 1962) ${ }^{16}$. Nie jest ono tożsame ze zbiorem wspólnych własności rozumianych na sposób (1), ale z serią lub seriami par uporządkowanych. Co to oznacza? Można percepcyjnie ująć w danym przedmiocie X pewną określoną własność $C$, którą wcześniej spostrzegło się przedmiocie Y, a która ze względu na czasowy porządek spostrzeżenia nie jest już w żaden sposób dostępna jako coś obecnego w aktualnym spostrzeżeniu (Piłat, 2006, s. 141-142). Rozpoznanie szeregu takich własności prowadzi do ujęcia danego przedmiotu $\mathrm{X}$ jako przedstawiciela tego samego typu, który przypisujemy przedmiotowi $\mathrm{Y}^{17}$.

Przypadek (3) dla moich celów jest najbardziej interesujący, ponieważ zdaje sprawę z dynamicznego charakteru doświadczenia oraz nie podziela słabości modeli opartych na klasycznej teorii pojęć ${ }^{18}$. Na jego niekorzyść przemawia

własności. Teoria ta zakłada również pewną koncepcję akwizycji języka oraz kategoryzacji (Machery, 2012, s. 78-79).

${ }^{15} \mathrm{~W}$ literaturze oprócz pojęcia relacji asymetrycznej mówi się o relacji przeciwsymetrycznej. Jest to taka relacja, która jeżeli zachodzi dla pary $(x, y)$, to nie zachodzi dla pary $(y, x)$.

${ }^{16}$ Amos Tversky w klasycznej pracy Cechy podobieństwa powiada, że podobieństwo przez większość filozofów i psychologów było uważane za przykład relacji symetrycznej. Takie rozumienie prowadzi jednak do traktowania podobieństwa jako relacji przechodniej, co zdaniem Tversky'ego jest błędem (Tversky, 2007, s. 523-524). Należy jednak podkreślić, że z istnienia symetryczności danej relacji nie musi wynikać jej przechodniość. Na przykład relacja bycia spokrewnionym jest relacją symetryczną, ale nieprzechodnią.

${ }^{17}$ Należy pamiętać, że zdaniem fenomenologów opisana sytuacja dotyczy tak zwanego doświadczenia przedpredykatywnego, czyli takiego, które poprzedza wszelką pojęciową kategoryzację czy przyporządkowanie do prototypu.

${ }^{18}$ Klasyczna i prototypowa teoria pojęć zakłada istnienie poziomu, który fenomenologowie opisują jako typikę doświadczenia. Owa przedpojęciowa warstwa doświadczenia oparta jest na istnieniu typów spostrzeżeniowych, które są skutkiem detekcji asymetrycznego podobieństwa. Dopiero tak rozumiana typika umożliwia pojęciową kategoryzację zakładaną przez wcześniej wspomniane teorie. Fenomenologiczna propozycja nie jest konkurencyjna dla teorii klasycznej i prototypowej, w tym sensie, że może je zastąpić. Ujawnia ona raczej poziom doświadczenia, który dla tych koncepcji jest niedostępny, a które w jakimś stopniu go zakładają (por. Piłat, 2007).

$\mathrm{W}$ tym aspekcie fenomenologiczne intuicje wydają się zbieżne z tezami głoszonymi w ramach koncepcji przetwarzania predykcyjnego. Oba ujęcia podkreślają ważność procesów percepcyjnych, które poprzedzają doświadczenie pojęciowe. 
czysto epistemiczna interpretacja typu. Asymetryczność podobieństwa wiąże się jedynie z niedostępnością poznawczą danej własności ${ }^{19}$. Typy oparte na asymetrycznym podobieństwie Husserl uznał za tak zwane typy pozaistotowe, które - inaczej niż istotowe (takie jak „gatunek”, „życie”) (Husserl, 2013, s. 316) - istnieją jedynie w swych egzemplifikacjach (Schütz, 1962, s. 283). Jak jest to możliwe?

W swoich analizach poświęconych tak zwanym pasywnym syntezom Husserl sformułował aprioryczne „prawo” dotyczące natury oczekiwania: coś podobnego przypomina coś innego, które to „coś” jest do niego podobne, a także pozwala oczekiwać tego, co podobne jako współistniejącego (Husserl, 1966, s. 185). Wydaje się zatem, że widzenie typów nieopartych na istocie jest ugruntowane w apercepcyjnym ujęciu wspólnych własności dla różnych przedmiotów. Czy aby na pewno? Apercepcja w takim ujęciu pełni funkcję detektora pewnych treści. O jakie jednak ostatecznie treści chodzi? Na to pytanie Husserl nie odpowiada.

Należy teraz stwierdzić, że apercepcja musi mieć charakter antycypacji, gdyby było bowiem inaczej, przedmioty doświadczane w czasie nie mogłyby być ujęte jako podpadające pod ten sam typ ${ }^{20}$. Rozpoznawalność typów jest oparta na antycypacyjnym ujęciu przedmiotów. Antycypacja jest zatem koniecznym warunkiem doświadczenia percepcyjnego ${ }^{21}$. Inaczej mówiąc gwarantuje ona, że docierające do podmiotu wrażenia są przeżywane jako spójne i powiązane z jego wcześniejszymi doświadczeniami. Antycypacyjne rozpoznanie danego typu pozwala zatem odróżnić fenomenologię typów od tradycyjnych koncepcji kategoryzacji, a także kognitywistycznej semantyki prototypu. Fenomen antycypacji umożliwia opis percepcji jako dynamicznego i czasowego sposobu doświadczania przedmiotów różnych modalności zmysłowych. Taką interpretację wzmacniają uwagi Husserla poświęcone fenomenowi normalności.

\footnotetext{
${ }^{19}$ Podobieństwo to w porządku ontycznym jest symetryczne i przechodnie. Uwagę tę zawdzięczam Piotrowi Kozakowi. W tej perspektywie pojawia się kluczowe pytanie o to, czy typ jest kategorią przedmiotową, czy poznawczą? Na to pytanie nie będę tutaj odpowiadać, wykracza ono bowiem poza przyjęte dla tych rozważań ramy, a w literaturze przedmiotu nie ma jednoznacznej zgody w tej kwestii. Można jednak bronić również ontycznej interpretacji podobieństwa asymetrycznego, tak jak czyni to na przykład Tversky. Jego zdaniem owa ontyczna asymetria pojawia się w przypadkach takich jak na przykład relacja podobieństwa zachodząca pomiędzy portretem a osobą, którą portret przedstawia. Można się zgodzić ze stwierdzeniem, że portret przypomina osobę, niemniej dość dziwnie brzmi zdanie „Osoba przypomina portret” (por. Tversky, Gati, 1982).

${ }^{20}$ Husserl powiada, że „przy przejściu ujęcia od $A$ do takiego samego lub podobnego $B$, to $B$ zostaje w świadomości doprowadzone do nakładającego się pokrycia z zatrzymywanym jeszcze w uchwycie $A$, i w obu jednakowe pokrywa się z jednakowym, a niejednakowe wdaje się w spór" (Husserl, 2013, s. 184-185).

${ }^{21} \mathrm{~W}$ tym kontekście doświadczenie można rozumieć w kategoriach złożonego, hierarchicznego systemu współzależnych od siebie typizacji (Pritchard, 1984, s. 309).
} 


\section{Antycypacje normalności}

Przeprowadzane przez Husserla analizy fenomenów normalności (Normalität) i anormalności (Abnormalität) uzupełniają znacząco rozważania nad antycypacją. Husserl powiada, że wszelkimi przeżyciami kierują antycypacje normalności, które polegają na przeniesieniu pewnej określonej informacji utworzonej przez wcześniejsze doświadczenia na doświadczenie obecne (Husserl, 1966, s. 186 ${ }^{22}$. Owa informacja ma charakter wzorcowy lub inaczej mówiąc optymalny (Wehrle, 2015, s. 131). Co to znaczy? Rozważę przykład podany przez Husserla $\mathrm{w}$ drugim tomie Idei. Codzienne doświadczenie poucza, że obok naturalnych tendencji pochodzących od innych osób, istnieją także pewne nie do końca określone wymogi czy normy, które narzuca tradycja i zwyczaj. „Ktoś” trzyma widelec w taki, a nie inny sposób, „ktoś” zachowuje się przy stole tak a tak (Husserl, 1974b, s. 269). Tego, co normalne, czyli typowe, wzorcowe czy standardowe, uczymy się pasywnie od innych (Zahavi, 2012, s. 176). To, co normalne, $\mathrm{z}$ jednej strony wiąże się z tym, co antycypacyjnie wnosi się do każdego nowego doświadczenia, z drugiej zaś odnosi się ono do tego, co konwencjonalne czy typowe. W obu przypadkach normalność jest tym elementem w doświadczeniu, która wykracza poza to, co indywidualne, ku temu, co ogólne (Husserl, 1973, s. 611).

Weźmy inny przykład: idę na spacer i spostrzegam po raz pierwszy jakiś budynek. Aktualnie widzę jego front, fragment prawej strony skierowanej do mnie, delikatny zarys dachu, który wydaje się do pewnego miejsca wznosić, a następnie opadać. Samego tego „opadania” nie dostrzegam jednak, ale mogę domniemywać, że niewidoczna dla mnie strona dachu jest spadzista. Domniemuję również, że dom z tyłu ma analogiczną strukturę do tego, co widzę aktualnie. Przy czym wiem, że może mieć on inny kształt, typowy jednak dla domów jednorodzinnych w Polsce. Jest więc albo zbudowany na planie kwadratu, albo na planie litery T. Nie jestem zaskoczony widząc tutaj taką a taką budowlę. Doświadczenie to jest dla mnie jak najbardziej normalne, jest bowiem oparte na antycypacji ukonstytuowanej na podstawie moich wcześniejszych spostrzeżeń budynków mieszkalnych w Polsce. Nie muszę tego domu obchodzić, zwiedzać czy wspiąć się na jego dach, bo już u p r z e d n i o wi e m z czym mam do czynienia. Owa uprzednia wiedza, która ma charakter antycypacyjny, ufundowana jest na wiedzy już posiadanej. W tym sensie antycypacja współkonstytuująca moje obecne doświadczenie nabiera charakteru normatywnego. Oznacza to, że dane doświadczenie normalizuje się lub, mówiąc inaczej, staje się optymalne $\mathrm{w}$ odniesieniu do istniejących już uprzednio norm spostrzegania czy działania, ufundowanych na przeszłych doświadczeniach (Wehrle, 2015,

${ }^{22} \mathrm{~W}$ sytuacji, w której odpowiednie antycypacje nie znajdują wypełnienia w określonej naoczności, ma się do czynienia z anormalnością, której nie należy mylić z jakąś patologią bądź ułomnością spostrzeżenia. 
s. 129). Istnienie antycypacji gwarantuje fenomenologiczną dostępność owych norm. Potwierdzeniem tego jest fakt, że Husserl wprowadził pojęcie normalności do opisu konstytucji przedmiotów w świecie intersubiektywnym, w Lebenswelt, który ze swej natury jest już normatywny (Steinbock, 1995, s. 243).

W świetle tych uwag można poczynić kilka istotnych modyfikacji proponowanego tu ujęcia. Antycypacje normalności są normatywne w sensie NW i NP. $\mathrm{Z}$ jednej strony są one ważne przedmiotowo, ponieważ odnoszą się do wszelkiego możliwego doświadczenia przedmiotów modalności zmysłowych. Owo odnoszenie się umożliwia mówienie o ich warunkach prawdziwościowych (NW). Z drugiej zaś są one ważne normatywnie (NP), ponieważ dzięki nim dane doświadczenie jest przeżywane jako obiektywnie ważne, czyli zobowiązujące podmiot do odpowiednich działań poznawczych i pozapoznawczych. Przykład używania sztućców sugestywnie pokazuje, jak istotną rolę w doświadczeniu pełni moment regularności czy powtarzalności odpowiednich działań czy sytuacji. Również analiza spostrzeżenia domu wskazuje, że owo doświadczenie jest typowe i optymalne, ponieważ jest warunkowane przez antycypacje, które umożliwiają przeżycie go jako typowego przeżycia spostrzeżenia domu. Owo rozpoznanie regularności, czy jak wcześniej mówiłem asymetryczności podobieństwa ${ }^{23}$, ma, co podkreślał wielokrotnie Husserl, charakter pasywny. Znaczy to, że w spontanicznym akcie poznania odbywa się ono bez udziału świadomego Ja ${ }^{24}$.

\section{Podwójna normatywnośćc ${ }^{5}$}

Antycypacja jest tym, co kształtuje charakter wszelkiego teraźniejszego doświadczenia. Jej normatywny charakter wynika stąd, że jest ona gwarantem przeżywania danych doświadczeń jako normalnych czy optymalnych. Akt rozpoznania Reksa jako typowego psa ufundowany jest na akcie antycypacji, która mając charakter ogólny, umożliwia pewien wgląd w cechy charakterystyczne czy typowe dla wszelkich psów. Psa „normalnie” doświadcza się jako posiadającego takie, a nie inne uzębienie, taki, a nie inny sposób zachowania, szczekającego tak a tak itd. To, że Reks w wyniku operacji strun głosowych nie może zaszczekać, nie wpływa istotnie na nasze jego doświadczenie jako przedstawiciela gatunku pies.

\footnotetext{
${ }^{23}$ Ową asymetryczność, jak sądzę, można by ostatecznie wiązać z rozpoznaniem tego, co regularne, wzorcowe.

${ }^{24}$ Pełne uzasadnienie tego twierdzenia wiąże się z koniecznością przejścia na poziom analiz genetycznych. Fenomenologia genetyczna pozwala opisać sposób, w jaki pojęciowa treść percepcyjna jest konstytuowana na poziomie przedrefleksyjnych i przedpojęciowych syntez pasywnych (Husserl, 1966, s. 295, 361, 444; por. także Crowell, 2013, s. 127).

${ }^{25} \mathrm{~W}$ niniejszym paragrafie korzystam z niektórych rozważań zawartych w mojej innej publikacji (Piekarski, 2016).
} 
Z innej strony rozpoznanie Reksa jako typu psa na podstawie antycypacji prowadzi do szeregu możliwych reakcji-działań wykonywanych przez podmiot. Widząc psa mogę zagwizdać, rzucić mu kość albo pójść z nim na spacer. Antycypacja, która umożliwiła typizację Reksa jako psa, normuje również szereg działań, które antycypujący podmiot może wykonać. Kiedy dane stworzenie rozpoznam jako wilka, to owo ufundowane na antycypacji rozpoznanie w sposób konieczny reguluje szereg moich działań. W takiej sytuacji mogę na przykład uciec, udawać nieruchomy przedmiot albo spróbować bronić się przed ewentualnym atakiem wilka. Jak widać, NP antycypacji ściśle wiąże się z jej regulatywnym charakterem jako reguły działania. Na podstawie danej antycypacji podmiot jest zobowiązany wykonać dane działania poznawcze i poza poznawcze. Nie musi on wykonać konkretnie tych działań, ale jest zobowiązany wykonać j a ki eś działania.

Należy zatem stwierdzić, że antycypacje charakteryzują się czymś, co od tej pory będę określać jako moc normatywną ${ }^{26}$. Pojęcie to $\mathrm{w}$ pewnym stopniu zapożyczam z teorii prawa, gdzie oznacza ono sposób, w jaki dana norma jest umiejscowiona $\mathrm{w}$ odniesieniu do innych norm. Odróżnia się moc prawną normy, która jest zależna od miejsca organu wydającego akt w hierarchii organów państwowych i od nazwy tego aktu, oraz moc obowiązującą, która jest identyczna dla wszystkich aktów (norm). Te pierwsza jest stopniowalna, ta ostatnia nie ${ }^{27}$. Proponowane przeze mnie pojęcie łączy oba te aspekty ${ }^{28}$ i oznacza stopień, w jakim dana funkcja czy mechanizm może oddziaływać na podmiot działania ${ }^{29}$. W przykładzie $\mathrm{z}$ wilkiem moc normatywna danej antycypacji będzie większa, w przykładzie z reksem zaś mniejsza. Z tej perspektywy antycypacje pozbawione mocy normatywnej nie są ostatecznie antycypacjami, a wydają się po prostu czystą fantazjąa ${ }^{30}$.

\footnotetext{
${ }^{26}$ Husserl normatywność różnego rodzaju aktów intencjonalnych ściśle wiązał z ich teleologiczną naturą, którą można zdaniem niektórych interpretować jako normatywną (Crowell, 2013, s. 24). Inaczej mówiąc: normatywność jest wewnętrznie przypisana do treści aktów (s. 129).

${ }^{27} \mathrm{~W}$ polskim prawodawstwie orzeka się dwa rodzaje mocy. Prawodawstwa w innych państwach nie zawsze odróżniają te dwa aspekty. Niektórzy teoretycy prawa mówią po prostu o mocy normatywnej aktów prawnych (por. Ávila, 2016, s. 481-495).

${ }^{28} \mathrm{~W}$ prawoznawstwie mówi się o tym, że akty prawne czerpią swoją moc normatywną ze stosunków ekonomicznych, moralności, układu sił politycznych, religii itd. W przypadku mocy normatywnej antycypacji lub predykcji jej źródłem wydaje się po prostu funkcja, jaką pełnią w poszczególnych mechanizmach poznawczych.

${ }^{29}$ Korsgaard (1996) normatywną moc bezpośrednio wiąże z podmiotem rozumianym jako podmiotu deliberacji i świadomego namysłu. Takie ujęcie jest jednak zbyt wąskie dla rozważań prezentowanych w tym artykule.

${ }^{30}$ Pytanie o to, czy fantazja może mieć normatywny charakter pozostawiam tutaj otwartym.
} 


\section{Przetwarzanie predykcyjne}

Wedle hipotezy proponowanej przez zwolenników koncepcji przetwarzania predykcyjnego (Clark, 2013, 2016; Friston, 2010, 2012; Hohwy, 2016; Wiese, Metzinger, 2017) podstawowym zadaniem mózgu jest minimalizacja błędu predykcyjnego, który pojawia się pomiędzy hipotezami tworzonymi w oparciu o model świata posiadanymi przez dany organizm a informacjami pochodzącymi ze świata, które są dostarczane przez zmysły (określone zbiory danych). Mózg w sposób ciągły tworzy statystyczne przewidywania, które funkcjonują jako reprezentacje tego, co się wydarza w świecie. Reprezentacje te są hierarchicznie zorganizowane i tworzone na poszczególnych poziomach modelu generatywnego. Następnie przy ich pomocy mózg przewiduje obecny i przyszły kształt danych docierających do niego za pośrednictwem wejść zmysłowych. Hierarchiczny model koresponduje z hierarchią zmiennych losowych odbieranych przez zmysły (Metzinger, Weisse, 2017, s. 3). Predykcje są z jednej strony warunkowane posiadanym przez dany system poznawczy wewnętrznym modelem świata, z drugiej zaś przez zmienne informacje napływające ze świata. Obie te warstwy wzajemnie się ograniczają, pozostając w dynamicznych zależnościach (Hohwy, 2013, s. 69-70). Opierając się na wiedzy dotyczącej przyczynowych zależności w świecie, umysł stawia hipotezy odnoszące się do prawdopodobieństwa zajścia pewnych zdarzeń. Dzięki temu może zminimalizować tak zwany błąd predykcyjny ${ }^{31}$. Ustalenia te opierają się na obserwacji, że informacje zmysłowe nie kształtują percepcji w sposób bezpośredni. Są one raczej w sposób aktywy dobierane i odpowiednio wykorzystywane. Predykcje kierują zatem tym, co jest spostrzegane, ale także sposobem integracji odpowiednich aspektów spostrzeganego świata. Problem percepcji w takim ujęciu dotyczy możliwości wykorzystania danych, które dochodzą do mózgu za pośrednictwem wejść zmysłowych w taki sposób, aby organizm nie popełniał błędów predykcyjnych. Błędy te zaś biorą się z nieznajomości przyczynowych źródeł pobudzeń zmysłowych. Nie istnieje bowiem jedno-jednoznaczna relacja zachodząca pomiędzy przyczynami i skutkami - różne przyczyny mogą wywoływać takie same skutki. Nieznajomość tych przyczyn w praktyce może stanowić zagrożenie dla danego organizmu.

Hohwy powiada, że koncepcja mózgu minimalizującego błąd predykcyjny nie wyjaśnia faktu percepcji, ale to w jaki sposób ona się odbywa. Tym samym ma ona bezpośrednie zastosowanie do fenomenologii percepcji (Hohwy, 2013,

\footnotetext{
${ }^{31}$ Według hipotezy predykcyjnej mózg generuje odpowiednie predykcje, szacując poziom swojej niepewności (Clark, 2016, s. 57). Szacowanie niepewności wiąże się wprost z tak zwaną precyzją. Im większą precyzję system przypisuje danemu błędowi predykcyjnemu, tym mniejszy jest ten błąd (Friston, 2010). Można powiedzieć, że precyzja pełni funkcję meta-reprezentacji w stosunku do każdego poziomu hierarchicznego modelu generatywnego (por. Adams, Stephan i in., 2013)
} 
s. 1) ${ }^{32}$. Co to znaczy? Predykcyjne podejście do percepcji ma dawać dostęp do wszystkich poziomów poznania zmysłowego, rozumiejąc je na wzór hierarchicznego porządku. Jest ono również wrażliwe na zróżnicowanie percepcyjne, a nie jak wiele innych teorii tylko na subtelności kategoryzacji pojęciowej. Nie chodzi tutaj zatem o zwykłe kategoryzowanie czy pojęciowe ujęcie (labelling), ale o osiągnięcie perspektywy pierwszoosobowej. Oznacza to, że sposób, w jaki mówi się o przedmiotach, jak się je ujmuje i ostatecznie kategoryzuje, jest ściśle zależny od tego, w jaki sposób przedmioty są widziane podczas czasowych zmian perspektywy. Kluczową dla wyjaśnienia natury percepcji okazuję się kwestia predykcji, które dokonuje system poznawczy podczas każdego kontaktu z rzeczywistością. W tej perspektywie problem percepcji ogniskuje się wokół pytania o to, w jaki sposób kształtowane są i wybierane prawdziwe hipotezy dotyczące świata (Hohwy, 2013, s. 16)? Inaczej mówiąc: w jaki sposób nie znając przyczyn stymulacji sensorycznych, mózg może na ich bazie wyprowadzać odpowiednie hipotezy ${ }^{33}$ ? Zadanie takie powinno polegać na ekstrapolacji określonych informacji z niepewnego zbioru danych. Przetwarzanie informacji w mózgu opiera się zatem na jakieś formie wnioskowania statystycznego.

Część badaczy (między innymi Harkness, Keshava, 2017; Hohwy, 2013, 2016) przyjmuje hipotezę bayesiańskiego mózgu, wedle której centralny system nerwowy konstruuje i testuje wewnętrzne modele świata zewnętrznego na drodze realizacji procesów poznawczych, które są aproksymacją wnioskowania bayesowskiego. Następnie wykorzystując hierarchicznie zorganizowane inferencje, mózg tworzy odpowiednie wielopoziomowe modele generatywne, które odgórnie generują hipotezy „interpretujące” oddolnie przychodzące informacje pochodzące z sygnału zmysłowego. Każdy poziom takiego modelu minimalizuje błędy predykcyjne na poziomie niższym: od wyższych procesów poznawczych (niektórzy badacze mówią też o tych realizowanych świadomie (por. Clark, 2017; Madary, 2015; Piekarski 2018b) aż po procesy neuronalne. Pojawiający się możliwy błąd predykcyjny, czyli nieodpowiedniość zachodząca pomiędzy predykacjami (hipotezy budowane w oparciu o wewnętrzny model świata) a stanem aktualnym rozpoznawanym na podstawie informacji pochodzącej

\footnotetext{
${ }^{32}$ Trzeba tutaj zaznaczyć, że rozumienie fenomenologii proponowane przez Hohwy'ego nie pokrywa się w sposób zupełny z koncepcją fenomenologii Husserla. Ten ostatni traktuje ją jako możliwie nieuprzedzony opis tego, co dane świadomości w swojej cielesnej samoobecności. Hohwy zaś, podobnie jak inni przedstawiciele filozofii umysłu czy analitycznej filozofii działania, przez „fenomenologię" rozumie opis doświadczenia w perspektywie pierwszoosobowej. Opis taki ma dać odpowiedź na pytanie ,jak to jest być (na przykład) świadomym podmiotem działania?”, czyli wyjaśnić tak zwaną świadomość fenomenalną.

${ }^{33} \mathrm{Z}$ powodu tej wątpliwości niektórzy badacze twierdzą, że w koncepcjach predykcyjnych percepcja może być rozumiana jako „kontrolowana halucynacja” (Grush, 2004) lub jako doświadczenie „wirtualnej rzeczywistości” (Hohwy, 2013, s. 137-138). Wiąże się to z głoszonym przez predykcjonizm przekonaniem, według którego z powodu nieznajomości przyczynowych źródeł pobudzeń zmysłowych mózg niejako musi je „zgadywać” (Clark, 2016, s. 2; por. Hutto, 2017 i krytyka jego ujęcia Piekarski, 2017).
} 
z wejść zmysłowych, może zostać zminimalizowany na dwa sposoby (Friston, 2010, s. 129):

(1) na drodze wnioskowania pasywnego (percepcyjnego), czyli rewizji modelu generatywnego oraz sformułowanych hipotez w odniesieniu do statystycznego sygnału zmysłowego;

(2) na drodze wnioskowania aktywnego, czyli poprzez takie działanie w świecie, które pozwoli utrzymać odpowiednią, sformułowaną przez model hipotezę, w taki sposób, aby „nasze predykcje stały się prawdziwe” (Clark, 2016, s. 121). Wykonując wnioskowanie aktywne podmiot ingeruje w przyczynową strukturę odpowiednich stanów rzeczy.

\section{Wnioskowanie aktywne}

Rozważmy następujący przykład: jadę w nocy dwupasmową drogą. Z naprzeciwka dostrzegam zbliżające się dwa świetlne punkty. Przewiduję, że są to światła samochodu, który jedzie z naprzeciwka. Zakładam również, że samochód z naprzeciwka jedzie właściwym pasem. Istnieje jednak ryzyko, że jedzie on pod prąd. Nie mam jednak pewności. W jaki zatem sposób mogę podjąć decyzję dotyczącą tego, co mam zrobić? Jeżeli moja reprezentacja ruchu wykonywanego przez samochód jadący naprzeciw mnie okaże się błędna, to błąd ten ostatecznie może mnie kosztować życie. Trafność utworzonej przeze mnie predykcji dotyczącej tego, co się zaraz wydarzy na drodze, nie tylko zależy od informacji, które do mnie docierają za pośrednictwem zmysłów, ale także mojej wiedzy, doświadczenia i przewidywań, które dokonuję.

Mówiąc językiem koncepcji przetwarzania predykcyjnego: muszę podjąć takie działanie (wnioskowanie aktywne), które zminimalizuje w sposób jak najbardziej optymalny pojawiający się błąd predykcyjny, to jest dysproporcję zachodzącą pomiędzy moimi przewidywaniami i wiedzą (wewnętrzny model świata) a informacjami docierającymi do mnie za pośrednictwem wejść zmysłowych. Minimalizacja błędu predykcyjnego jest możliwa przy założeniu hierarchicznej struktury modelu generatywnego, w którym informacje zmysłowe obecne na niższych poziomach modelu są interpretowane przez znajdujące się wyższych poziomach oczekiwania (predykcje), co ściśle wiąże się z przypisywaniem tym błędom odpowiedniego stopnia precyzji. Wcześniejsza wiedza (Prior) zostaje powiązana z informacjami pochodzącymi ze zmysłów, co wywołuje pojawienie się odpowiedniej reprezentacji świata (Hohwy, 2013, s. 32).

Błąd predykcyjny zostanie zminimalizowany dopiero wtedy, gdy model przyjmie najlepszą możliwą hipotezę dotyczącą przyczyn źródła sygnału zmysłowego. Na podstawie tej hipotezy tworzone są następnie predykcje warunkujące działania danego systemu poznawczego czy organizmu. Model, co podkreślałem, jest wielopoziomowy, dzięki czemu każdy poziom modelu minimalizuje 
błąd predykcyjny na poziomie niższym. W przykładzie z samochodem, jeden poziom modelu (wyższy) dotyczyć będzie możliwości rozpoznania świetlnych punktów jako świateł samochodowych, inny (niżej leżący) będzie odnosił się na przykład do percepcji krawędzi spostrzeganego przedmiotu, kolejny poziom będzie generował predykcje dotyczące przykładowo czasu, w jakim może dojść do kolizji obu pojazdów itd. Na każdym poziomie model szacuje, na ile precyzyjny jest dany błąd predykcyjny, tak aby można było dokonać rewizji dotychczas przyjętych hipotez (por. Friston, 2009, s. 299).

Na podstawie powyższych analiz należy stwierdzić, że wnioskowanie aktywne pełni niebanalną funkcję $\mathrm{w}$ procesie minimalizacji błędów predykcyjnych i wiąże się bezpośrednio z kwestią działań, które dany system poznawczy może podjąć. Od teraz system ten będę określał mianem aktywnego podmiotu (por. Friston, 2009). Przez to pojęcie należy rozumieć taki system biologiczny, który funkcjonując w zmiennym i dynamicznym środowisku, minimalizuje możliwe błędy predykcyjne.

Friston podkreśla, że minimalizacja błędów predykcyjnych opiera się na „niskopoziomowej” normatywności biologicznej, która odnosi się do utrzymywania systemu żywego $\mathrm{w}$ stanie dalekim od równowagi termodynamicznej. Jest ona przez niego wiązana z tak zwaną free-energy principle (FEP), zakładającą minimalizację swobodnej energii (w sensie informacyjnym), w celu osiągnięcia homeostazy (Friston, Daunizeau i in., 2010; Friston, Stephan, 2007) ${ }^{34}$. Zdaniem Fristona przy pomocy FEP można wyjaśnić zdolność złożonych systemów, takich jak na przykład ludzki mózg, do samoorganizacji, która jest niczym innym jak tendencją do unikania zaburzeń, czyli pewną wewnętrzną potrzebą utrzymania homeostatycznej równowagi ze środowiskiem. Minimalizacja swobodnej energii pozwala również na analizę kosztów informacji podczas działania i wyjaśnienie racjonalności procesów podejmowania decyzji. Według Fristona musi istnieć jakieś istotne powiązanie pomiędzy teorią informacji (rozumianą $\mathrm{w}$ sensie termodynamiki statystycznej) a zachowaniami adaptacyjnymi danego podmiotu, analizowanymi w terminach optymalnej teorii decyzji (Friston, 2012: s. 2102). Aktywny podmiot na drodze wnioskowania aktywnego minimalizuje możliwe błędy predykcyjne. Jak należy to rozumieć?

Wyobraźmy sobie następującą sytuację: jestem przekonany o tym, że jeżeli spadnie deszcz, to będę musiał znaleźć suche schronienie. Będę zmuszony zatem podjąć takie optymalne działania, które niejako spełnią (fulfill) te przewidywania. Friston podkreśla, że moje wcześniejsze przekonania nie odnoszą się

\footnotetext{
${ }^{34}$ Swobodna energia jest miarą energii potrzebną do wykonania odpowiedniego działania. Jest ona, mówiąc słowami Clarka, różnicą pomiędzy tym, w jaki sposób świat jest modelowany przez model generatywny, a tym jaki świat jest (Clark, 2016, s. 305). Innymi słowy: czym mniejsza jest ta różnica, tym podmiot działający może skuteczniej działać w świecie. FEP, zdaniem Fristona, odnosi się do wszystkich biologicznych systemów i wiąże się z ich umiejętnością przeciwstawiania się naturalnej tendencji do nieporządku (utożsamianą przez niego z entropią).
} 
do stanów rzeczy, ale do sposobu, w jaki mam działać (policy). Znaczy to, że błędy predykcyjne są minimalizowane przy pomocy działań. Można powiedzieć, że zarówno działania (wnioskowanie aktywne), jak i percepcja (wnioskowanie percepcyjne) próbują minimalizować błędy predykcyjne, czyli potencjalne zaskoczenie (suprise), które wiąże się z pojawianiem się kolejnych informacji przychodzących za pośrednictwem wejść zmysłowych (Friston, 2013, s. 2-3).

Na drodze wnioskowania aktywnego model generatywny tworzy zstępujące proprioceptywne predykcje, a nie określone komendy motoryczne, które jak w wielu innych ujęciach w sposób oddolny miałyby generować takie, a nie inne działania. Centralny system nerwowy implementując regułę Bayesa, wytwarza odpowiednie predykcje ukierunkowane na wybór optymalnych działań w terminach oczekiwanych konsekwencji (Friston, Daunizeau i in., 2010, s. 235). Ta ostania uwaga jest kluczowa, ponieważ pozwala wykazać, że predykcje obecne we wnioskowaniu aktywnym nie są zorientowane na stany rzeczy w świecie, ale na określone konsekwencje planowanych działań (por. Adams, Ship, Friston, 2013).

\section{Normatywność predykcji}

Przeprowadzone dotychczas analizy pozwalają stwierdzić, że model generatywny przyjmuje określoną hipotezę na temat przyczynowego źródła docierających informacji. W oparciu o tę hipotezę generuje na kolejnych poziomach swojej hierarchicznej struktury odpowiednie predykcje, które pozwalają zminimalizować pojawiające się rozbieżności pomiędzy nadchodzącym oddolnym sygnałem a odgórnie przyjętą hipotezą. Minimalizacja błędów predykcyjnych odbywa się na dwa sposoby: albo (1) na drodze modyfikacji wewnętrznych parametrów modelu (dostosowywanie hipotez do statystycznego wzorca obecnego w sygnale docierającym przez wejścia zmysłowe), albo (2) realizując wnioskowanie aktywne, które polega na zaplanowaniu i przewidzeniu konsekwencji takich działań, które dzięki ingerencji w przyczynową strukturę stanów rzeczy pozwalają zmienić charakter napływającego sygnału (lub urzeczywistniają przyjętą uprzednio przez model hipotezę). W obu przypadkach wygenerowane predykcje pełnią kluczową funkcję w minimalizacji możliwych błędów predykcyjnych. Przyjrzę się teraz temu bliżej.

Hasłowo rzecz ujmując: aktywny podmiot w oparciu o sformułowaną przez siebie hipotezę podejmuje odpowiednie działania, które mają doprowadzić do takiej ingerencji w przyczynową strukturę świata, która uczyni odpowiednią hipotezę bardziej prawdopodobną bądź prawdziwą. Charakter podjętych działań jest uwarunkowany określonymi predykcjami. Wracając do przykładu z autostradą: to jakie działania podejmę, jest ściśle zależne od wygenerowanych przeze mnie predykcji, które z jednej strony dotyczą przyszłych stanów rzeczy 
(na przykład czy zgodnie z przyjętą hipotezą samochód jadący z naprzeciwka mnie uderzy), z drugiej strony zaś konsekwencji działań, które mogę wykonać celem uniknięcia przewidzianej przez hipotezę stłuczki.

W zależności od tego, jakie predykcje model generatywny wygeneruje, takie działania podejmie aktywny podmiot. Relacja zachodząca pomiędzy utworzonymi predykcjami a potencjalnymi działaniami nie jest jednak relacją o charakterze czysto przyczynowym, w tym sensie, że za każdym razem wygenerowana przez model predykcja $a$ wywołuje w sposób konieczny działanie $X$. W sensie ogólnym predykcje są racjami działań rozumianymi jako ich przyczyny, jednak zależność ta ma również charakter normatywny ${ }^{35}$. W \$1 stwierdziłem, że predykcja jest normatywna w tym sensie, że zobowiązuje dany organizm czy system poznawczy do takiego, a nie innego działania. Jej normatywny charakter w sensie pierwotnym (NP) oznacza, że jest ona konstytutywna dla wyboru i kontroli działań, które pozwalają na minimalizację błędów predykcyjnych. Tym samym jest ona również konstytutywna dla struktury i treści modelu generatywnego. Zasadne jest również mówienie o normatywnym (w sensie NW) charakterze predykcji utworzonych przez model. Z jednej strony bowiem predykcje regulują wybór takich, a nie innych działań (NP), z drugiej zaś mogą one faktycznie wpływać na wybór takich, a nie innych działań, ponieważ możliwe jest przypisanie im odpowiednich wartości logicznych(NW). Predykcje charakteryzują się również określoną mocą normatywną. Predykcja, że samochód jadący po autostradzie ma niebieski kolor, tworzy dużo słabsze zobowiązanie niż predykcja głosząca, że ten samochód jedzie pod prąd.

Normatywność predykcji można wywodzić z „niskopoziomowej” normatywności biologicznej, opisywanej przez Fristona w kategoriach minimalizacji swobodnej energii (sensie informacyjno-teoretycznym). W myśl FEP każdy żywy organizm jest zobligowany minimalizować swobodną energię wykonując takie, a nie inne działania (Friston, 2009).

Opierając się na koncepcji Fristona można stwierdzić, że predykcje swoją normatywną funkcję wywodzą $\mathrm{z}$ tak, a nie inaczej ewolucyjnie ukształtowanego mózgu. Myliłby się jednak ten, kto normatywność redukowałby tylko do roli biologicznej. Faktycznie na niższych poziomach funkcjonowania organizmu normatywna funkcja predykcji ogniskuje się wokół fristonowskiej FEP, czyli wymogu samoregulacji (to jest uniknięcia „śmierci” termodynamicznej), jednak na poziomach wyższych ściśle wiąże się ona $\mathrm{z}$ wiedzą posiadaną przez aktywny podmiot oraz z charakterystycznymi dla niego zasadami postępowania (policy), które wprost odnoszą się do sfer preferencji, motywacji oraz pragnienień (Friston i in., 2017; Schwartenbeck i in., 2013). Wydaje się, że sfery te na-

\footnotetext{
${ }^{35}$ Problem ten szczegółowo omawiam w innej mojej publikacji (Piekarski, 2018b).
} 
leży interpretować w kategoriach kolejnych poziomów reprezentacyjnego modelu generatywego ${ }^{36}$. Zgodnie $\mathrm{z}$ tą myślą wyższe warstwy tego modelu zakładają poziomy: pojęciowy, samowiedzy i preferencji podmiotowych, ale także określone sfery uczuć, emocji i motywacji. Elementem scalającym poszczególne poziomy tego modelu są - w myśl koncepcji przetwarzania predykcyjnego - organizujące doświadczenie świata predykcje obecne na wszelkich jego poziomach: od neuronalnego aż do poziomu świadomego przeżywania i podejmowania decyzji ${ }^{37}$.

\section{Przetwarzanie predykcyjne a fenomenologia antycypacji}

Z wielu powodów teoria przetwarzania predykcyjnego stanowi interesujące i nietrywialne podejście do percepcji. Na swój sposób jest ona odnowieniem kantowskiego podejścia do problemu poznania, jednak dzięki korzystaniu z odkryć z zakresu współczesnych neuronauk, biologii czy fizyki jest pozbawiona spekulatywnego wymiaru obecnego w myśli autora Krytyki czystego rozumu ${ }^{38}$. Trudno jednoznacznie orzec, czy teoria ta spełni pokładane w niej nadzieje. Koncepcja przetwarzania predykcyjnego z jednej strony ma dość silne ugruntowanie $\mathrm{w}$ badaniach empirycznych, $\mathrm{z}$ drugiej zaś strony sami jej zwolennicy nie mają pełnej jasności, co do jej ostatecznego charakteru. Mianowicie: czy jest to tylko teoria neuronaukowa wyjaśniająca elementarne procesy percepcyjne na poziomie neuronalnym, czy może ona jednak wyjaśnić również wyższe, w tym świadomie realizowane, procesy poznawcze, takie jak na przykład kategoryzacja czy samowiedza ${ }^{39}$ ? Problematycznym wciąż pozostaje pytanie o to, który z poziomów opisu wskazanych przez Davida Marra (1982) dotyczy modeli przetwarzania predykcyjnego: czy (1) implementacji, określający fizyczne własności systemu, czy (2) algorytmiczny, który określa reprezentacje i algorytmy,

\footnotetext{
${ }^{36}$ Zwolennicy radykalnie ujętego przetwarzania predykcyjnego (Radical Predictive Processing) (Clark, 2015; Orlandi, 2016, 2017) twierdzą, że tylko pewne elementy modelu generatywnego można interpretować jako reprezentacyjne. Innego zdania są na przykład Hohwy (2016) czy Gładziejewski (2016). Podejście umiarkowane prezentuje Dolega (2017).

${ }^{37}$ Można tutaj postawić hipotezę, że predykcje pozwalają tworzyć strategie i metastrategie działania dla danego podmiotu. Problem ten jednak wymaga dalszych analiz.

Prezentowana perspektywa pozwala również stwierdzić, że normatywność predykcji generowanych przez wyższe warstwy modelu generatywnego jest sposobem realizacji normatywności biologicznej („,niskopoziomowej”). Hipoteza ta jednak wymaga dalszych badań, które wykraczają poza ramy tego artykułu

${ }^{38} \mathrm{U}$ Kanta, podobnie jak w predykcjonizmie, problemem pozostaje wyjaśnienie tego, jakie zjawiska czy przedmioty stanowią przyczyny pobudzeń zmysłowych (por. Swanson, 2016).

${ }^{39}$ Powyższy problem ściśle łączy się z wielką rozbieżnością stanowisk w obrębie tradycji, które $\mathrm{w}$ jakimś stopniu $\mathrm{z}$ teorią przetwarzania predykcyjnego się wiążą. Od enaktywizmu i teorii ekologicznych (por. Bruineberg, 2017) przez koncepcje umysłu rozszerzonego (por. Allen, Friston, 2016; Clark, 2015, 2016) aż po filozofię biologii (por. Friston, 2012; Kirchhoff, Froese, 2017). Na niebezpieczeństwa związane z zastosowaniem koncepcji przetwarzania predykcyjnego zwracają uwagę Gallagher i Allen (2016).
} 
czy może (3) komputacyjny, określający funkcje systemu (Harkness, Keshava, 2017)? Na to pytanie, przy obecnym stanie badań, nie można podać jednoznacznej odpowiedzi. Część badaczy zwraca uwagę na brak odpowiednich świadectw neurologicznych, które potwierdzałyby hipotezę mózgu bayesiańskiego (Bowers, Davis, 2012). Wątpliwości może również budzić kwestia wskazania odpowiednich mechanizmów, które miałyby wyjaśniać modele predykcyjne. Zwolennicy predykcjonizmu bronią się na różne sposoby, jednak również wśród nich nie ma jasności co do ostatecznego metodologicznego charakteru tej koncepcji.

Bruineberg (2017) wskazuje, że istnieją przynajmniej trzy podstawowe filozoficzne interpretacje predykcjonizmu: (1) racjonalistyczna (Clark, 2013, 2016; Hohwy, 2013), (2) cybernetyczna (Seth, 2015) oraz (3) enaktywistyczna, korzystająca z pojęcia afordancji (Bruineberg, 2017; Bruineberg, Kiverstein, Rietveld, $2016)^{40}$. Clark podkreśla, że koncepcje predykcyjne pozwalają na analizę filozoficznych problemów z zakresu teorii umysłu rozszerzonego oraz społecznego (Clark, 2016, s. 10), u podstaw których leżą rozważania fenomenologów takich jak Edmund Husserl, Maurice Merleau-Ponty czy Aron Gurwitsch. W niniejszych rozważaniach interesuje mnie to, czy fenomenologiczne analizy mogą istotnie i w sposób nietrywialny wzbogacić rozważania z zakresu teorii przetwarzania predykcyjnego.

Tym, co szczególnie odróżnia koncepcje predykcyjne od fenomenologii jest: (1) przekonanie, że relacja poznawcza jest warunkowana przyczynowo, a nie intencjonalnie, to znaczy statystyczne wzorce obecne w sygnale zmysłowym są wynikiem pobudzeń zmysłowych opartych na regularnościach przyczynowych, oraz (2) twierdzenie, że perspektywa pierwszoosobowa jest kształtowana na drodze przyczynowych interakcji zachodzących pomiędzy światem a podmiotem działającym w świecie, co oznacza, że tak rozumiany podmiot nie jest żadnym wyróżnionym elementem doświadczenia warunkującym jego przebieg i odkrywanym w refleksji transcendentalnej (między innymi na drodze analizy intencjonalnej i po zabiegu redukcji transcendentalnej).

\section{a) Normatywność percepcji}

Zarówno teoria przetwarzania predykcyjnego, jak i propozycja Husserla zakładają aktywny charakter procesów percepcyjnych. Zgodne są również co do tego, że antycypacje oraz predykcje są kluczowymi elementami umożliwiają-

\footnotetext{
${ }^{40}$ Jako kryterium podziału dla różnych ujęć idei przetwarzania predykcyjnego można również wskazać stosunek ich autorów do reprezentacji: od stanowisk konserwatywnych (por. Hohwy, 2013; Gładziejewski, 2016) przez umiarkowane (Clark, 2013, 2015, 2016; Dolega, 2017) aż po ekologiczne, rezygnujące w jakimś stopniu z pojęcia reprezentacji (por. Bruineberg, 2017; Bruineberg, Kiverstein, Rietveld, 2016; Orlandi, 2016, 2017).
} 
cymi powiązanie informacji zmysłowej z wewnętrznym modelem świata, którym dysponuje podmiot lub system poznawczy. Interesującym mnie aspektem jest normatywność percepcji. Analizy z zakresu fenomenologii antycypacji przekonująco wykazują, że aktualne doświadczenie za sprawą swojej czasowej struktury jest warunkowane przez antycypacje. Z jednej strony antycypacje za sprawą typiki doświadczenia normują obecne przeżycia, z drugiej zaś stanowią one normatywne racje kształtujące przyszłe działania, które antycypujący podmiot może wykonać.

Z punktu widzenia predykcjonizmu poziom, o którym mówił Husserl zakłada już poziom predykcji rozumianych jako hipotezy bayesowskie realizowane przez model generatywny (od poziomu neuronalnego aż po świadome procesy decyzyjne i motywacyjne). Na razie brakuje konkretnych badań i analiz, które wykazałyby, że predykcje mają moc normatywną na poziomach świadomego działania i interakcji społecznych ${ }^{41}$. Wyjaśnienie predykcyjne tych zjawisk zakłada konieczność uwzględnienia sfer uczuć, preferencji, wyznawanych wartości itd. Są to zjawiska jak dotąd ujmowane przez predykcjonistów bardzo pobieżnie. Istnieją jednak pewne przesłanki, które pozwalają przypuszczać, że predykcje pełnią ważną funkcję normatywną na omówionym przed chwilą poziomie. Teoria przetwarzania predykcyjnego może z pewnością skorzystać z fenomenologicznych analiz antycypacji a także typiki doświadczenia. Przyjrzyjmy się skrótowo temu drugiemu problemowi.

\section{b) Rozpoznawanie typów a rozpoznawanie wzorców}

Kluczową kwestią dla modeli predykcyjnych jest stwierdzenie, że system poznawczy nie jest w stanie odkryć przyczynowych źródeł pobudzeń zmysłowych. Z tego powodu twierdzi się, że celem wnioskowania aktywnego jest predykcja ukrytych przyczyn tychże pobudzeń w środowisku ${ }^{42}$. Owa niemożność ściśle wiąże się z faktem istnienia błędów predykcyjnych. Na obecnym etapie rozwoju wydaje się, że badaczy przetwarzania predykcyjnego zadowala powyższa konstatacja, co w praktyce oznacza, że większą część swojej uwagi poświęcają analizie podmiotowej, czyli warunkom, jakie musi zrealizować podmiot, aby utworzyć odpowiednią predykcję. Analiza ta jest dość satysfakcjonująca, oparta jest bowiem zarówno na najnowszych wynikach z zakresu nauk

\footnotetext{
${ }^{41}$ Część badaczy stawia już sobie za zadanie analizę wyższych, świadomych poziomów modelu generatywnego. Andy Clark wraz ze współpracownikami od 2017 roku realizuje program badawczy Expecting Ourselves: Embodied Prediction and the Construction of Conscious Experience finansowany przez European Research Council. Jego celem jest wyjaśnienie natury i możliwości świadomego doświadczenia przez pryzmat koncepcji predykcyjnego mózgu. Więcej na ten temat patrz: https://www.x-spect.org/ (dostęp 25.01.2018).

${ }^{42}$ Innego zdania jest Bruinberg (inspirujący się fenomenologią Merleau-Ponty'ego i psychologią ekologiczną Gibsona), który twierdzi, że chodzi raczej o ukierunkowanie (steer) interakcji ze środowiskiem $\mathrm{w}$ taki sposób, aby system poznawczy rozumiany jako podmiot działania mógł się w pełni rozwijać w odpowiednim dla siebie otoczeniu (Bruinberg, 2017, s. 10).
} 
szczegółowych, jak i danych eksperymentalnych. Zaniedbana jest jednak strona przedmiotowa tego zagadnienia, czyli analiza przyczynowych zależności zachodzących pomiędzy stanami rzeczy obecnymi w środowisku danego systemu poznawczego. Jest to problem, z którym borykał się również Kant, nie umiejąc wyjaśnić przyczyn odbieranych przez nas zjawisk. Twierdził on, że nie mogą to być rzeczy same w sobie, ponieważ znajdują się one poza sferą wszelkiego możliwego doświadczenia.

Współczesne badania z zakresu kognitywistyki i deep learning oraz machine learning pozwalają stwierdzić, że procesy percepcyjne, uczenia się, nabywania języka, rozpoznawania twarzy itd. opierają się na zdolności do rozpoznawania wzorców (pattern recognition). Skrótowo rzecz ujmując: percepcja jest możliwa dzięki temu, że istnieją pewne stałe, regularne i nielosowe elementy w doświadczeniu zmysłowym, które pozwalają organizować nam dane obecne w statystycznym sygnale zmysłowym. Dzięki wzorcom informacje docierające do mózgu za pośrednictwem modalności zmysłowych są w jakimś stopniu uporządkowane i - co szczególnie istotne - można na ich podstawie przewidywać dalszy przebieg danego doświadczenia.

Należy zatem stwierdzić, że do pełnego wyjaśnienia procesów predykcyjnych konieczna jest analiza zdolności do rozpoznawania wzorców oraz natury samych wzorców. Z całą pewnością pomiędzy umiejętnością tworzenia hipotez percepcyjnych a zdolnością do rozpoznawania wzorców istnieje pewnego rodzaju relacja zwrotna, ale dotychczasowe analizy prawie nic na temat natury tej relacji nie mówią. Niektórzy badacze jednak zwracają uwagę na fakt, że na wyższych poziomach modelu generatywnego system poznawczy spostrzega raczej wzorce niż indywidualne różnice (Hohwy, 2013, s. 69).

Wydaje się, że w tym miejscu fenomenologia antycypacji może istotnie zainspirować badania z zakresu przetwarzania predykcyjnego. Typ zinterpretowany wcześniej (§4) jako zbiór własności opartych na asymetrycznym podobieństwie jest w pewnym sensie protoplastą współczesnego pojęcia wzorca. Taka interpretacja typów najlepiej zdaje sprawę z dynamicznego wymiaru doświadczenia oraz nie podziela słabości modeli opartych na klasycznej teorii pojęćc ${ }^{33}$. Pojawia się jednak problem, który został przez fenomenologię nierozwiązany, mianowicie kwestia tego, w jaki sposób apercepcja typów może być apercepcją treści, które nie są dane w jednym interwale czasowym. Inaczej mówiąc: co gwarantuje identyczność przeżyć intencjonalnych rozpoznawania danej treści $C$ obecnej w momencie czasowym $\mathrm{t}_{1} \mathrm{w}$ obiekcie $\mathrm{X}$ i tej samej treści $C$ obecnej $\mathrm{w}$ momencie czasowym $\mathrm{t}_{2}$ w obiekcie Y? Czy jest to identyczność struktury przeżyć, ich treści, czy może raczej identyczność własności, które są ujmowalne w przeżyciach? Są to pytania, które odsyłają raczej do analiz z zakresu

${ }^{43}$ Uwaga ta odnosi się również do pojęcia wzorca, który przeważnie jest rozumiany jako: (1) szablon (the theory of template), czyli mniej lub bardziej wierna kopia rzeczywistego zdarzenia albo jako (2) cecha lub ich zbiór (the theory of features). 
nauk kognitywnych, a więc i teorii przetwarzania predykcyjnego. Charakterystyka typu podana przez fenomenologię jest czysto epistemiczna. Kognitywistyczne podejście do wzorców ujmuje raczej ich charakterystykę ontyczną, niemniej trudno ją wprost powiązać z koncepcją przetwarzania predykcyjnego ze względu na postulowaną przez nią nieznajomość przyczyn pobudzeń zmysłowych ${ }^{44}$.

W tym kontekście pomocną może okazać się fenomenologiczna koncepcja antycypacyjnego przeniesienia, czyli przetworzenia danej informacji, pochodzącej od określonego przedmiotu spostrzeganego w przeszłym doświadczeniu, na inny przedmiot, który jest obecny w teraźniejszym spostrzeżeniu (Husserl, 1966, s. 186). Antycypacyjne przeniesienie jest przez Husserla wiązane $z$ antycypacjami normalności, które można w świetle hipotezy predykcyjnej zinterpretować jako pewne stabilne predykcje (stanowiące względnie stały element modelu generatywnego), służące jako podstawa do formułowania nowych hipotez. Trwałość tych pierwszych jest zagwarantowana ciągłością i powtarzalnością określonych doświadczeń percepcyjnych. Dopiero jakaś istotna zmiana w strukturze łańcuchów przyczynowych może istotnie zmodyfikować te bazowe hipotezy. Husserl powiada, że jeżeli nasze trwałe antycypacje nie znajdują potwierdzenia w doświadczeniu, to należy je zmienić. Okazują się one nieadekwatne, nietypowość nowego spostrzeżenia nie tyle jest bowiem jakąś formą patologiczną obecną w percepcji, ile normą, wedle której powinno się sformułować nowe hipotezy. W tym kontekście można przywołać uwagę Hohwy’ego, który twierdzi, że mózg, jeżeli ma zminimalizować błąd predykcyjny, to niejako musi doprecyzowywać nowe hipotezy w oparciu o wnioskowaniu już przeprowadzone. Nie wystarczy bowiem samo rozpoznawanie odpowiednich zależności w świecie (Hohwy, 2013, s. 66).

\section{Transcendentalny a empiryczny sposób wyjaśniania normatywności}

Analizy przeprowadzone w $\$ 11$ pozwalają stwierdzić, że relacja pomiędzy koncepcjami predykcyjnymi a fenomenologią z całą pewnością może mieć charakter heurystyczny. Fenomenologia wykorzystując zupełnie inne metody i przyjmując inne założenia w punkcie wyjścia niż teorie $\mathrm{z}$ zakresu kognitywistki, może zaoferować badaczom przetwarzania predykcyjnego konceptualne narzędzia służące do formułowania nowych hipotez badawczych, wyznaczających swoisty horyzont rozumienia. Pozwala ona również wskazywać interesujące kierunki interpretacji surowych danych dostarczanych przez nauki empiryczne. Taka zależność pomiędzy obydwoma sposobami badania percepcji jest jednak, w moim odczuciu, niesatysfakcjonująca i na podstawie obserwacji już

\footnotetext{
${ }^{44} \mathrm{~W}$ innym miejscu zaproponuję hipotezę, wedle której wzorce percepcyjne można potraktować jako dennettowskie real patterns, czyli jako rozpoznawalne regularności, które daje się ująć w formie skończonego opisu lub algorytmu.
} 
historycznych relacji pomiędzy fenomenologią a na przykład filozofią analityczną można zasadnie wątpić w to, czy fenomenolodzy i kognitywiści będą chcieli z tych heurystyk skorzystać.

Problem relacji fenomenologii i koncepcji przetwarzania predykcyjnego można również sprowadzić do sporu pomiędzy transcendentalnym a empirycznym (naturalistycznym) podejściem do badania procesów poznawczych. W kontekście niniejszych rozważań spór ten przybiera postać pytania o charakter wyjaśnienia tego, czym jest normatywność. Fenomenologowie proponują podejście oparte na umotywowanych przez doświadczenie opisach. Z jednej strony normatywność jest własnością przeżyć intencjonalnych (między innymi omawianej tutaj antycypacji i typiki), z drugiej zaś sam opis fenomenologiczny jest traktowany jako normatywnie ważny, to znaczy nie jest prostą deskrypcją tego, co jest poddane opisowi, ale eksplikacją warunków możliwości danego doświadczenia. Oznacza to, że opisowi poddana nie tyle jest sama faktyczność przeżyć, ile warunki, które dane przeżycia muszę spełniać, aby zostały ukonstytuowane jako takie, a nie inne. Przyjmując tę perspektywę, należy uznać, że normatywność jest wpisana w fenomenologię jako jej kluczowe założenie. Jeżeli nie uzna się opisów fenomenologicznych za normatywne, to trudno mówić o fenomenologii jako badaniu fundamentalnym nad sensem doświadczenia. Jeżeli zaś opis fenomenologiczny jest zdawaniem sprawy z tego, c o się jawi i jak się jawi świadomości, to jego uzasadnienie staje się jednocześnie uzasadnieniem fenomenologicznej koncepcji normatywności. Uzasadnienie opisu jest jednak problematyczne, ponieważ doświadczenie ujęte $\mathrm{w}$ fenomenologicznej deskrypcji nie pozwala na żadną weryfikację tej deskrypcji (Piłat, 2006, s. 26). Fenomenologiczne badanie zmierza od doświadczenia do opisu, jednak zasadne wątpliwości budzi pytanie o to, czy droga odwrotna jest możliwa.

Inaczej sprawa wygląda w przypadku koncepcji przetwarzania predykcyjnego. Tutaj nie ma się do czynienia $z$ opartymi na przeżyciach opisami, ale na efektywnych, czyli weryfikowalnych i w jakimś stopniu potwierdzalnych doświadczalnie, wyjaśnieniach ${ }^{45}$. Normatywność z całą pewnością nie należy do słownika bazowego teorii kognitywistycznych. Nie inaczej jest w przypadku omawianej koncepcji. Normatywny charakter odpowiednich funkcji czy mechanizmów może zostać jedynie wykazany. Zasadną wątpliwość może jednak budzić samo użycie pojęcia normatywności w kontekście empirycznie motywowanej teorii. Wielu badaczy zamiast mówić o normatywności, proponuje ujęcia wykorzystujące na przykład wyjaśnienia ewolucyjne, oparte na pojęciach doboru naturalnego, mechanizmów uspołeczniania czy empatii (por. Churchland, 2013; de Waal, 2014; Tomasello, 2015). W perspektywie diachronicznej jest to

${ }^{45} \mathrm{Nie}$ jest jednak jak dotąd jasne, z jakiego rodzaju wyjaśnianiem ma się do czynienia w tej koncepcji. 
ujęcie jak najbardziej usprawiedliwione, jednak w perspektywie synchronicznej wydaje się, że mówienie o normatywności może być również zasadne. Jak wykazały przeprowadzone tutaj analizy mechanizmów predykcyjnych, normatywność jest obecna na każdym z poziomów modelu generatywnego. Gdyby chcieć z tego pojęcia zrezygnować, to należałoby w alternatywny sposób wyjaśnić „zobowiązujący”46 charakter predykcji i wnioskowania aktywnego. Argumentem przeciwko mówieniu o normatywności jest fakt, że wielu badaczy obywa się bez tego pojęcia. Nie znaczy to jednak, że w ich koncepcjach nieobecne są problemy powiązane z normatywnością. Dobrym tego przykładem są modele powołujące się na regułę Bayesa, która jest regułą normatywną, to znaczy mówiącą, jakie idealne warunki musi spełniać model, aby był wartościowy eksplanacyjnie ${ }^{47}$. Wydaje się, że badania nad normatywnością w teoriach empirycznych będą z czasem zyskiwały na znaczeniu i mogą stanowić interesującą kontrpropozycję dla koncepcji filozoficznych.

Twierdzę, że perspektywa badań nad normatywnością wyznaczana przez koncepcje predykcyjne ma tę przewagę nad podejściem fenomenologicznym, że pozwala potraktować to zjawisko w kategoriach biologicznych. Rozumiem to następująco: analizy z zakresu przetwarzania predykcyjnego nie mówią, jakie poznanie (hipotetycznie) p o w in n o być, aby można było je traktować jako informacyjne i informujące, ale jakie faktycznie j e st . Naturalistyczne wyjaśnienie mechanizmów poznawczych pozwala zatem (1) na ich empiryczną weryfikację, (2) na przewidywanie i tłumaczenie innych zjawisk ${ }^{48}$ oraz (3) umożliwia takie uzasadnienie ludzkich działań, decyzji czy postępowania, które nie musi odwoływać się do niejasnego pojęcia racjonalności, ale do konkretnych mechanizmów poznawczych, rozumianych w tym kontekście jako mechanizmy predykcyjne. Znaczy to, że normatywne standardy, które traktuje się jako miarę racjonalności, są w jakimś stopniu oparte na takiej, a nie innej biologicznej konstytucji osoby ludzkiej (por. Schwartenbeck i in., 2013). Uwaga ta nie jest bez znaczenia dla dalszych analiz praktyk, reguł czy tworów normatywnych.

\footnotetext{
${ }^{46}$ Friston w wielu publikach, analizując wnioskowanie aktywne, używa angielskiego wyrażenia „obliged”.

${ }^{47} \mathrm{Na}$ temat znaczenia tak zwanych normatywnych modeli w wyjaśnieniu ludzkiej wiedzy patrz: (Elqayam, Over, 2016). Oaksford i Chater (2009) uważają, że normy probabilistyczne lepiej pasują do wyjaśniania ludzkiej racjonalności niż reguły logiki klasycznej. Warto przytoczyć w tym kontekście słowa Schwartenbecka i jego współpracowników, że FEP, która stanowi konstytutywny element koncepcji przetwarzania predykcyjnego, jest normatywna w tym sensie, że dostarcza dobrego wyjaśnienia dla percepcji i działań podejmowanych przez system poznawczy (Schwartenbeck i in., 2013).

Można by zaryzykować stwierdzenie, że problem normatywności jest obecny implicite w praktykach badawczych wielu naukowców.

${ }^{48}$ Interesujące jest na przykład zastosowanie modeli predykcyjnych w wyjaśnianiu natury psychoz (por. Adams, Stephan i in., 2013; Sterzer i in., 2016).
} 


\section{Zakończenie}

Celem artykułu było (1) wykazanie normatywnego charakteru antycypacji analizowanych przez fenomenologię; (2) pokazanie, że predykcje pełnią określone normatywne funkcje w procesach percepcyjnych opisywanych w ramach koncepcji przetwarzania predykcyjnego; (3) uzasadnienie tezy, według której analizy mechanizmów normatywnych przeprowadzane przez badawczy przetwarzania predykcyjnego są bardziej efektywne i pozwalają na pełniejsze wyjaśnienie normatywności, niż ma to miejsce w fenomenologii. Podsumowując niniejsze badania można powiedzieć, że wyjaśnienia w przetwarzaniu predykcyjnym mają charakter normatywny, ponieważ normatywne są same mechanizmy predykcyjne. Mechanizmy te zaś są normatywne, ponieważ spełniają warunki, które muszą zajść, aby dane działania (poznawcze i pozapoznawcze) mogły zostać podjęte.

Istotne jest również to, że na podstawie przeprowadzonych tutaj analiz z zakresu fenomenologii antycypacji i przetwarzania predykcyjnego można postawić nietrywialną hipotezę badawczą, według której normatywne intuicje dotyczące świata i innych podmiotów wywodzą się wprost z doświadczenia percepcyjnego świata.

\section{Bibliografia}

Adams, R. A., Shipp, S., Friston, K. J. (2013). Predictions not commands: active inference in the motor system. Brain Structure \& Function, 218(3), 611-643. doi: 10.1007/s00429012-0475-5.

Adams R. A., Stephan K. E., Brown H. R., Frith C. D., Friston K. J. (2013). The computational anatomy of psychosis. Frontiers in Psychiatry, 30(3). doi: 10.3389/fpsyt.2013.00047.

Allen, M., Friston, K. J. (2016). From cognitivism to autopoiesis: towards a computational framework for the embodied mind. Synthese, 1-24. doi:10.1007/s11229-016-1288-5.

Ávila H. (2016). Cetrainty in Law, Springer: Law and Philosophy Library 114. doi: 10.1007/978-3-319-33407-3.

Bielawska, M. (2013). Specyfika problematyki czasu w Husserlowskiej fenomenologii. In W. Płotka (Ed.). Wprowadzenie do fenomenologii. Interpretacje, zastosowania, problemy. T. 1. Warszawa: Wydawnictwo IFIS PAN, 266-292.

Burge, T. (2000). Origins of Objectivity. Oxford: Oxford University Press.

Bowers, J. S., Davis C. J. (2012). Bayesian just-so stories in psychology and neuroscience. Psychological bulletin, 138 (3), 389-414. doi:10.1037/a0026450.

Bickhard, M., Process and Emergence: Normative Function and Representation. In: J. Seibt (ed.). Process Theories. Crossdisciplinary studies in dynamic categories. Dordrecht: Springer 2003, 121-155. DOI: 10.1007/978-94-007-1044-3_6. 
Bickhard, M. The interactivist model, Synthese 3(2009)166, 547-591. DOI: 10.1007/s11229008-9375-x.

Bruineberg, J. (2017). Active Inference and the Primacy of the 'I Can'. In T. Metzinger \& W. Wiese (Eds.). Philosophy and Predictive Processing. Frankfurt am Main: MIND Group. doi: 10.155027/9783958573062.

Bruineberg, J., Kiverstein, J., Rietveld, E. (2016). The anticipating brain is not a scientist: the free-energy principle from an ecological-enactive perspective. Synthese, 1-28. doi: 10.1007/s11229-016-1239-1.

Churchland, P. S. (2013). Moralność mózgu. Co neuronauka mówi o moralności, M. Hohol, N. Marek (tłum.), Kraków: Copernicus Center Press.

Clark, A. (2013). Whatever next? Predictive brains, situated agents, and the future of cognitive science. Behavioral and Brain Sciences, 36, 181-204. doi:10.1017/S0140525X12000477.

Clark, A. (2015). Embodied Prediction. T. Metzinger \& J. M. Windt (Eds). Open MIND: 7(T) (267-287). Frankfurt am Main: MIND Group. doi: 10.15502/9783958570115.

Clark, A. (2016). Surfing Uncertainty. Prediction, Action and the Embodied Mind. Oxford: Oxford University Press.

Clark A. (2017). Scaling the Peaks: Probabilistic Brains and the 'All-or-Nothing' Nature of Agentive Experience. www.x-spect.org/uploads/9/8/1/5/98154170/scalingthepeaksfull.pdf, 02.06.2017.

Crowell, S. (2013). Normativity and Phenomenology in Husserl and Heidegger, Cambridge: Cambridge University Press.

De Waal, F. (2014). Natural Normativity: The 'Is' and 'Ought' of Animal Behavior. Behaviour, 151, 185-204.

Dolega, K. (2017). Moderate Predictive Processing. In T. Metzinger \& W. Wiese (Eds.). Philosophy and Predictive Processing. Frankfurt am Main: MIND Group. doi: 10.15502/9783958573116.

Ferencz-Flatz, Ch. (2014). A Phenomenology of Automatism. Habit and Situational Typification in Husserl. Phenomenology and Mind, 6, 64-83.

Elqayam, S., Over, D. E. (2016). From Is to Ought: The Place of Normative Models in the Study of Human Thought. Frontiers in Psychology, 7. doi: 10.3389/978-2-88919-896-2.

Friston, K. J. (2003). Learning and inference in the brain. Neural Networks, 16, 13251352.

Frison, K. J. (2009). The free-energy principle: a rough guide to the brain?. Trends Cogn Sci. 13(7), 293-301. doi: 10.1016/j.tics.2009.04.005.

Friston, K. J. (2010). The free-energy principle: A unified brain theory? Nature Neuroscience, 11, 127-138.

Friston, K. J. (2012). Free Energy Principle for Biological Systems. Entropy, 14, 2100-2121.

Friston K. J., Daunizeau J. Kilner, J., Kiebel, S. J. (2010). Action and behavior: a free-energy formulation. Biological Cybernetics, 102(3), 227-260. 
Friston, K. J., Schwartenbeck, P., FitzGerald, T., Moutoussis, M., Behrens, T., Dolan, R. J. (2013). The anatomy of choice: active inference and agency. Frontiers in Human Neuroscience, 7, 598. doi: 10.3389/fnhum.2013.00598.

Friston, K. J., Stephan K. E. (2007). Free-energy and the brain. Synthese,159, 417-458.

Friston, K. J. Lin, M., Frith, C. D., Pezzulo, G., Hobson, J. A., Ondobaka, S. (2017). Active Inference, Curiosity and Insight. Neural Comput. 29(10), 2633-2683.

Gallagher, S., Allen, M. (2016). Active inference, enactivism and the hermeneutics of social cognition. Synthese, 1-22. doi:10.1007/s11229-016-1269-8.

Gładziejewski, P. (2016). Predictive coding and representationalism. Synthese, 193, 559582. doi: 10.1007/s11229-015-0762-9.

Grush, R. (2004). The emulation theory of representation: Motor control, imagery, and perception. Behavioral and Brain Sciences, 27 (3), 377-396.

Gunther, Y. H. (Ed.) (2003). Essays on Nonconceptual Content. Cambridge MA: MIT Press.

Harkness, D. L., Keshava, A. (2017). Moving from the What to the How and Where Bayesian Models and Predictive Processing. In T. Metzinger \& W. Wiese (Eds.). Philosophy and Predictive Processing. Frankfurt am Main: MIND Group. doi: $10.15502 / 9783958573178$.

Hohwy, J. (2013). The predictive mind. Oxford: Oxford University Press.

Hohwy, J. (2016). The self-evidencing brain. Noûs,50(2), 259-285.

Hopp, W. (2010). How to Think about Nonconceptual Content. The New Yearbook for Phenomenology and Phenomenological Philosophy, 10, 1-24.

Husserl, E. (1966). Analysen zur passiven Synthesis. Aus Vorlesungs- und Forschungsmanuskripten 1918-1926. Den Haag: Martinus Nijhoff.

Husserl E. (1973). Zur Phänomenologie der Intersubjektivität. Texte aus der Nachlass. Dritter Teil: 1929-1935. Den Haag: Martinus Nijhoff.

Husserl E. (1974a). Idee czystej fenomenologii i fenomenologicznej filozofii ks. I. D. Gierulanka (tłum.). Warszawa: PWN.

Husserl, E. (1974b). Idee czystej fenomenologii i fenomenologicznej filozofii ks. II. D. Gierulanka (tłum.). Warszawa: PWN.

Husserl, E. (1989). Wykłady z fenomenologii wewnętrznej świadomości czasu. J. Sidorek (tłum.). Warszawa: PWN.

Husserl, E. (2013). Doświadczenie i sąd. Badania nad genealogią logiki. B. Baran (tłum.). Warszawa: Fundacja Aletheia.

Hutto D. D. (2017). Getting into predictive processing's great guessing game: Bootstrap heaven or hell?. Synthese, 1-14. doi: 10.1007/s11229-017-1385-0.

Kirchhoff, M. D.; Froese, T. (2017). Where There is Life There is Mind: In Support of a Strong Life-Mind Continuity Thesis. Entropy, 19. doi:10.3390/e19040169.

Kleiber, G. (2003). Semantyka prototypu. Kategorie i znaczenia leksykalne. B. Ligara (tłum.). Kraków: Universitas. 
Korsgaard, Ch. (1996). The Sources of Normativity. New York: Cambridge University Press.

Kozak, P. (2015). Co to jest myślenie? Pojęcia, sądy, percepcja w perspektywie kantowskiej. Warszawa: Semper.

Lohmar, D. (2013). Die Funktion des Typus in Wahrnehmung und Erkennen bei Menschen und Tieren. Ein Beitrag zur Frage nach der kleinsten Einheit des Erkennens. In I. Römer, M. Wunsch (Eds.). Person. Paderborn: Verlag Mentis, 147-167.

Lohmar, D. (2014). Types and Habits. Habits and their Cognitive Background in Hume and Husserl. Phenomenology and Mind, 6, 48-63.

Machery, E. (2012). Doing without Concepts. New York: Oxford University Press.

Madary, M. (2012). Husserl on Perceptual Constancy. European Journal of Philosophy. 20, 145-165

Madary, M. (2015). Extending the Explanandum for Predictive Processing - A Commentary on Andy Clark. In T. Metzinger \& J. M. Windt (Eds). Open MIND: 7(C) (289-298). Frankfurt am Main: MIND Group, 289-298. doi: 10.15502/9783958570313.

Marr, D. (1982). Vision: A Computational Investigation into the Human Representation and Processing of Visual Information. New York: Freeman.

Mazijk, C. van. (2017). Phenomenological Approaches to Non-conceptual Content. HORIZON. Studies in Phenomenology, 1(6), 58-78

McDowell, J. (1994). Mind and World. Cambridge, MA: Harvard University Press.

Oaksford, M., Chater, N. (2009). Précis of Bayesian rationality: the probabilistic approach to human reasoning. Behavioral and Brain Sciences, 32, 69-84. doi: 10.1017/S0140525X09000284

Orlandi, N. (2016). Bayesian perception is ecological perception. Philosophical Topics, 44(2), 327-351.

Orlandi, N. (2017). Predictive perceptual systems. Synthese, 1-20. doi: 10.1007/s11229017-1373-4.

Piekarski, M. (2016). Od typiki doświadczenia do normatywnej antycypacji. Przyczynek do fenomenologii normatywności. Filo-Sofia, 33(2), 71-86.

Piekarski, M. (2017). Commentary: Getting into predictive processing's great guessing game: Bootstrap heaven or hell?. Frontiers in Psychology, 8:1244. doi: 10.3389/fpsyg.2017.01244.

Piekarski, M. (2018a). One or many normativities?. Studia Philosophiae Christianae, 1. Filozofia normatywności, 1-15. doi: 10.21697/spch.2018.54.1.11. w druku.

Piekarski, M. (2018b). Two arguments supporting the thesis about the predictive nature of reasons for action. Studia Philosophiae Christianae, 1. Filozofia normatywności, 120. doi: 10.21697/spch.2018.54.1.14. w druku.

Piłat, R. (2006). Asymetryczność podobieństwa. In Doświadczenie i pojęcie. Studia z fenomenologii i filozofii umystu. Warszawa: Wydawnictwo IFIS PAN, 141-142. 
Piłat, R. (2007). O istocie pojęć. Warszawa: Wydawnictwo IFIS PAN.

Pritchard C. W. (1984) Type and Eidos-Schutz and Husserl, Journal of the British Society for Phenomenology, 15(3), 307-311. doi: 10.1080/00071773.1984.11007684.

Robbins, Ph., Murat A. (2008). "A Short Primer on Situated Cognition". In The Cambridge Handbook of Situated Cognition, eds. Ph. Robbins, Murat A. (Cambridge, MA: Cambridge University Press).

Rosch, E. (1978). Principles of Categorization. In E. Rosch, B. Lloyd (Eds.). Cognition and Categorization. Hillsdale: Laurence Erlbaum Ass., 27-48.

Rowlands, M. (2012). Representing without representations. Avant, 1(3), 133-144.

Schütz, A. (1962) Collected Papers. Natanson M. (ed.). The Hague: Martinus Nijhoff.

Schwartenbeck, P., FitzGerald, T., Dolan, R. J., Friston, K. J. (2013). Exploration, novelty, surprise, and free energy minimization. Frontiers in Psychology. doi: 10.3389/fpsyg.2013.00710.

Seth, A. K. (2015) The cybernetic Bayesian brain. In T. K. Metzinger \& J. M. Windt (Eds.) Open Mind. Frankfurt am Main: MIND Group. doi: 10.15502/9783958570108.

Steinbock A. J. (1995) Phenomenological concepts of normality and abnormality. Man and World, 28 (3), 241-260.

Sterzer, P., Mishara, A. L., Voss, M., Heinz, A. (2016). Thought Insertion as a Self-Disturbance: An Integration of Predictive Coding and Phenomenological Approaches. Frontiers in Human Neuroscience, 10, 502. doi: 10.3389/fnhum.2016.00502.

Swanson, L. R. (2016). The Predictive Processing Paradigm Has Roots in Kant. Frontiers in Systems Neuroscience,79(10). doi: 10.3389/fnsys.2016.00079.

Tomasello M. (2015). Historia naturalna ludzkiego myślenia, B. Kucharzyk, R. Ociepa (tłum.), Kraków: Copernicus Centre Press.

Tversky, A. (2007). Cechy podobieństwa. R. Balas (tłum.)., In Z. Chlewiński (ed.). Psychologia poznawcza w trzech ostatnich dekadach XX wieku. Gdańsk: GWP, 521-557.

Tversky, A., Gati, I. (1982). Similarity, separability, and the triangle inequality. Psychological Review, 89, 123-154.

Wehrle M. (2015) Normality and Normativity in Experience. In: Doyon M., Breyer T. (Eds.). Normativity in Perception. Basingstoke: Palgrave McMillan, 128-140.

Wiese, W., Metzinger T. (2017). Vanilla PP for Philosophers: A Primer on Predictive Processing. In T. Metzinger \& W. Wiese (Eds.). Philosophy and Predictive Processing. Frankfurt am Main: MIND Group. doi: 10.15502/9783958573024.

Youguo, Pi. et al. (2008). Theory of cognitive pattern recognition. In Peng-Yeng Yin (Ed.) Pattern recognition techniques, technology and applications (433-463). In Tech. doi: 10.5772/6251.

Zahavi, Dan. 2012. Fenomenologia Husserla. Przeł. M. Święch. Kraków: WAM. 


\title{
Normativity of Anticipation and Normativity of Prediction. Two Approaches: Phe- nomenology and Predictive Processing Theory
}

\begin{abstract}
The aim of the present article is (1) to analyse the normative character of anticipations described by phenomenology; (2) to demonstrate, within the framework of the predictive processing approach, that predictions fulfill a specific normative function in the perceptual process; and (3) to justify the thesis according to which the analyses of normative mechanisms performed by investigators of predictive processing are more effective and give better explanations of normativity than those offered by phenomenology. I would like to justify the thesis that explanations in the predictive processing approach are normative in nature. They are like that because prediction mechanisms themselves are normative.
\end{abstract}

Keywords: perception; prediction; anticipation; normativity; predictive processing; phenomenology; explanation. 